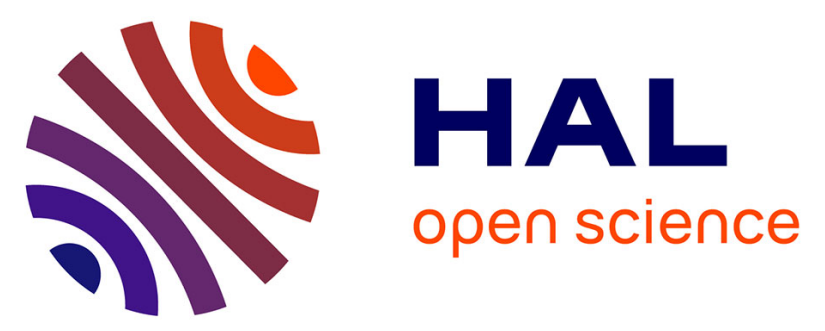

\title{
Synthesis and cytotoxicities of 7 -aza rebeccamycin analogues bearing various substituents on the sugar moiety, on the imide nitrogen and on the carbazole framework
}

\author{
S. Messaoudi, Fabrice Anizon, S. Leonce, A. Pierre, B. Pfeiffer, M. \\ Prudhomme
}

\section{To cite this version:}

S. Messaoudi, Fabrice Anizon, S. Leonce, A. Pierre, B. Pfeiffer, et al.. Synthesis and cytotoxicities of 7-aza rebeccamycin analogues bearing various substituents on the sugar moiety, on the imide nitrogen and on the carbazole framework. European Journal of Medicinal Chemistry, 2005, pp.961-971. 10.1016/j.ejmech.2005.04.002 . hal-00125819

\section{HAL Id: hal-00125819 \\ https://hal.science/hal-00125819}

Submitted on 5 Mar 2007

HAL is a multi-disciplinary open access archive for the deposit and dissemination of scientific research documents, whether they are published or not. The documents may come from teaching and research institutions in France or abroad, or from public or private research centers.
L'archive ouverte pluridisciplinaire HAL, est destinée au dépôt et à la diffusion de documents scientifiques de niveau recherche, publiés ou non, émanant des établissements d'enseignement et de recherche français ou étrangers, des laboratoires publics ou privés. 


\title{
Synthesis and cytotoxicities of 7-aza rebeccamycin analogues bearing various substituents on the sugar moiety, on the imide nitrogen and on the carbazole framework
}

\author{
Samir Messaoudi ${ }^{\mathrm{a}}$, Fabrice Anizon ${ }^{\mathrm{a}}$, Stéphane Léonce ${ }^{\mathrm{b}}$, Alain Pierré ${ }^{\mathrm{b}}$, \\ Bruno Pfeiffer ${ }^{\mathrm{b}}$, Michelle Prudhomme ${ }^{\mathrm{a}, *}$ \\ ${ }^{a}$ Université Blaise Pascal, Synthèse et Etude de Systèmes à Intérêt Biologique, UMR 6504 du CNRS, 63177 Aubière, France \\ ${ }^{\mathrm{b}}$ Institut de Recherches Servier, 125 Chemin de Ronde, 78290 Croissy-sur-Seine, France
}

\begin{abstract}
The synthesis of a family of rebeccamycin analogues in which one indole unit has been replaced by a 7-azaindole moiety is described. Substitutions have been carried out on the imide nitrogen, on the carbazole framework and on the sugar part. Compounds with a lactam upper heterocycle have also been prepared. The cytotoxicities of the newly synthesized compounds toward four tumor cell lines, one murine leukemia (L1210) and three human tumor cell lines (prostate carcinoma DU145, colon carcinoma HT29, and non-small cell lung carcinoma A549) have been evaluated and compared to those of rebeccamycin and parent non-aza and aza compounds.
\end{abstract}

Keywords: Rebeccamycin; 7-Azaindole; Antitumor compounds; Topoisomerase I inhibitors

\section{Introduction}

A large number of indolocarbazoles of biological interest are provided by bacteria [1]. Among them, rebeccamycin $\mathbf{1}$ (Fig. 1) is a microbial metabolite isolated from cultures of Saccharothrix aerocolonigenes. Its antitumor activity is linked to its capacity to induce topoisomerase I-mediated DNA cleavage [2,3]. Large structure-activity relationship studies on rebeccamycin have been carried out by several academic and industrial groups. Various families of rebeccamycin analogues have been prepared either by total synthesis or by semisynthesis from the bacterial metabolite, and their biological properties have been evaluated $[4,5]$.

It has been shown that if topoisomerase I remains the first target for most of the analogues, there are very likely other targets for these indolocarbazole compounds and preliminary studies have shown that kinases involved in the progression of the cell cycle could also be responsible for their anti-

\footnotetext{
* Corresponding author. Tel.: +33 4734071 24; fax: +334 73407717 .

E-mail address: Michelle.PRUDHOMME@univ_bpclermont.fr (M. Prudhomme).
}

proliferative activities [6]. Results with compounds bearing substitutions at the imide nitrogen suggested that, in the ternary complex DNA-topoisomerase I-drug, this moiety could be located in a pocket of the enzyme allowing bulky functional groups [3]. Substitutions performed at the 6'-position on the carbohydrate part of rebeccamycin showed that these substitutions could modify the biological targets. For example, compared with rebeccamycin, 6'-amino derivatives exhibit an enhanced capacity to interact with DNA but they do not behave as topoisomerase I inhibitors showing that topoisomerase I inhibition and DNA interaction correspond to two separate mechanisms. DNA and topoisomerase I can be distinct targets for indolocarbazole compounds [7], as already observed with anthracycline derivatives, which, according to the substitutions, can be either topoisomerase II poisons or only DNA intercalators [8].

3,9-Substituents on the indolocarbazole framework can enhance or abolish the cytotoxicity but also induce selectivity toward the tumor cell lines tested. 3,9-Substituted compounds can behave as DNA intercalators and topoisomerase I inhibitors (dihydroxymethyl or diamino and dihydroxy substituents), some of them can behave as topoisomerase I inhibi- 


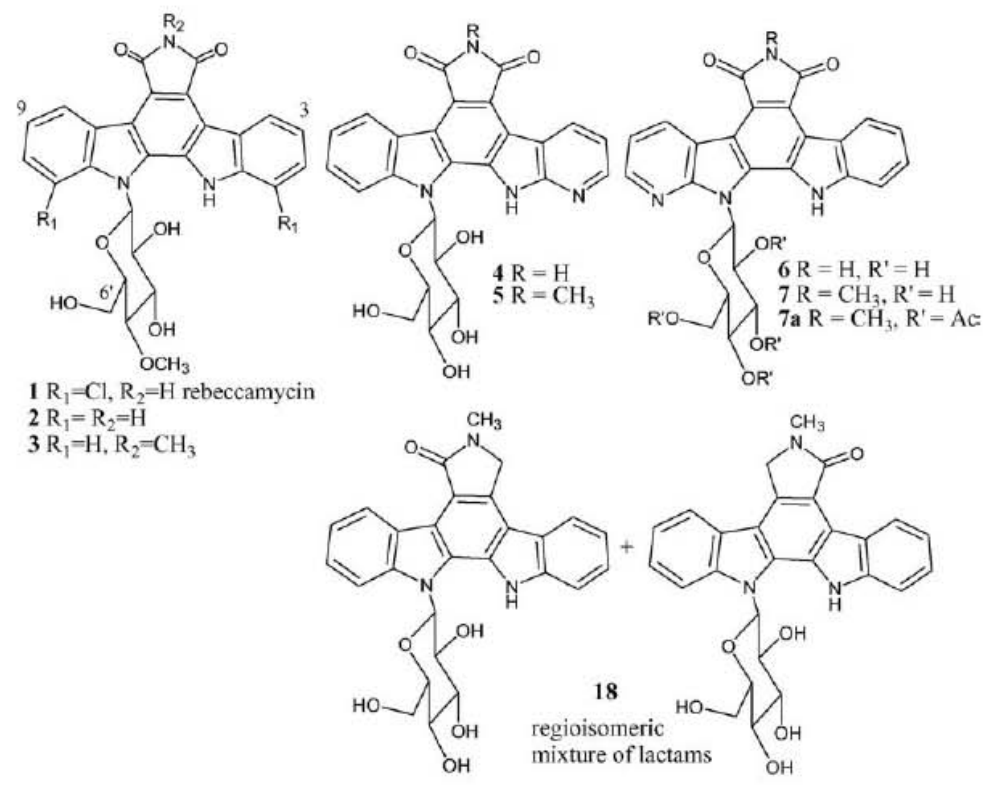

Fig. 1. Rebeccamycin and aza analogues.

tors but without intercalating properties (diformyl and dinitro substituents) [6]. 7-Aza rebeccamycins have been recently synthesized and studied $[9,10]$. In contrast with rebeccamycins possessing two indole moieties, most of the 7-aza rebeccamycins exhibit a very interesting profile of cytotoxicity with a high selectivity for some tumor cell lines with $\mathrm{IC}_{50}$ values in the nanomolar range. DNA binding experiments showed major differences between the compounds bearing the carbohydrate unit either on the azaindole moiety or on the indole part. Compounds bearing the sugar unit on the indole exhibited higher affinity for DNA than non-aza analogues, but compounds with the sugar linked to the azaindole have lost their DNA binding properties. Compounds bearing the sugar unit on the indole are much more potent topoisomerase I inhibitors than compounds with the sugar linked to the azaindole. In these series, there is a closed correlation between DNA binding and topoisomerase I poisoning. In this paper, the synthesis of new 7-azaindolyl rebeccamycins $\mathbf{8 - 2 0}$ are reported together with their in vitro antiproliferative activities against four tumor cell lines (one murine L1210 leukemia, and three human tumor cell lines: DU145 prostate carcinoma, A549 non-small cell lung carcinoma, and HT29 colon carcinoma).

\section{Results and discussion}

\subsection{Chemistry}

In the series of compounds in which the carbohydrate unit is linked to the 7-azaindole moiety, anhydride $\mathbf{8}$ was prepared from compound A [7] (Scheme 1) in two steps. Reaction of $\mathbf{A}$ with aqueous sodium hydroxide in THF led to the formation of anhydride B with concomitant removal of the acetyl protective groups on the sugar moiety. Oxidative photocyclization of $\mathbf{B}$ in the presence of iodine afforded anhydride $\mathbf{8}$.

Reaction of anhydride $\mathbf{8}$ with hydrazine hydrate, hydroxylamine and diethylaminoethylamine gave compounds $\mathbf{9 , 1 0}$ and 11, respectively (Scheme 1). Substitution with a chlorine atom selectively at $6^{\prime}$ position on the sugar part (compound 12) was performed from compound 7 [7], by reaction with triphenylphosphine and $\mathrm{CCl}_{4}$ in pyridine [11] (Scheme 2).

Nitration at 3-position on the carbazole moiety was carried out from 7a [9] tetraacetylated on the sugar part using DMSO/ $/ \mathrm{Ac}_{2} \mathrm{O}$ affording 13a (Scheme 2). This technique was initially chosen to induce nitration in 10 position according to nucleophilic nitrations reported on dihydrodipyridopyrazines and isoquinolines $[12,13]$. In these compounds, an electrophilic intermediate is formed which reacts with the heterocyclic nitrogen atom to form a carbonium ion in ortho position with respect to the nitrogen atom. A nucleophilic attack by $\mathrm{NO}_{2}{ }^{-}$leads to ortho nitration. In our case, the nitration did not occur on the azaindole moiety but in the 3-position on the indole unit. A possible mechanism could be an electrophilic substitution at the 3-position, as usually observed with nonaza rebeccamycin analogues $[6,14,15]$, by $\mathrm{NO}_{2}{ }^{+}$formed from an electrophilic intermediate as shown on Scheme 3.

The position of the nitro group in 13a was assigned from NMR experiments (Fig. 2). A NOESY 2D showed a NOE effect between the indolic $\mathrm{NH}$ proton and the proton shifted at $7.66 \mathrm{ppm} .{ }^{1} \mathrm{H}-{ }^{1} \mathrm{H}$ COSY showed a coupling between the proton (d) at $7.66 \mathrm{ppm}$ and the proton (dd) at $8.41 \mathrm{ppm}$ (coupling constant $J=9.0 \mathrm{~Hz}$ ) as well as a coupling of the proton at $8.41 \mathrm{ppm}$ with the proton at $10,01 \mathrm{ppm}$ (coupling constant $J_{\text {meta }}=2,0 \mathrm{~Hz}$ ). Deacetylation of 13a was carried out with $\mathrm{NH}_{3} / \mathrm{MeOH}$.

Compound $\mathbf{1 4}$ was prepared from $\mathbf{5}$ using the method described for the synthesis of $\mathbf{1 2}$. However, in this case, the 


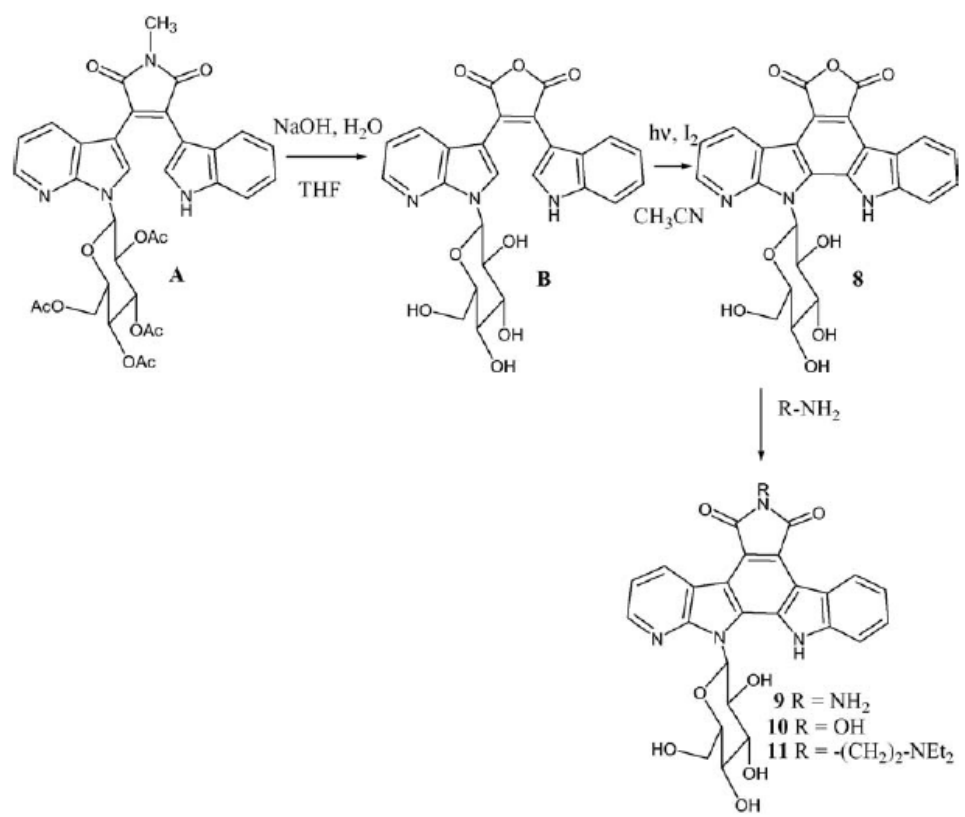

Scheme 1. Synthetic scheme for the preparation of compounds 8-11.

reaction gave two products: the $6^{\prime}$-monochloro derivative $\mathbf{1 4}$ and the $3^{\prime}, 6^{\prime}$-dichloro derivative $\mathbf{1 5}$ (Scheme 4). ${ }^{1} \mathrm{H}$ NMR spectra of compounds $\mathbf{1 4}$ and $\mathbf{1 5}$ in DMSO showed the presence of two conformers. The ratio of the conformers determined on the signals of $\mathrm{H}_{1^{\prime}}(6.41$ and $6.58 \mathrm{ppm})$ was $0.6: 1$ for 14. The presence of conformers was confirmed by ${ }^{1} \mathrm{H}$ NMR experiment at $70{ }^{\circ} \mathrm{C}$. It can be noticed that the presence of conformers was not observed with the $6^{\prime}$-chloro derivative 12. Conformers have been previously observed with 6 '-chloro non-aza analogues and in dechlorinated rebeccamycin analogues $[7,16]$. In the case of the compound 12, the "closed conformation" is very probably preferred due to a possible additional hydrogen bond between the nitrogen of the 7-azaindole and the 2'-hydroxyl hydrogen (Fig. 3). In dichloro compound 15, the ratio of the conformers determined from the ${ }^{1} \mathrm{H}$ NMR spectrum in DMSO on the signals of $\mathrm{H}_{1}$, (6.54 and $6.69 \mathrm{ppm}$ ) was 0.8:1 although in a mixed solvent DMSO/MeOH (1:3 v/v) the ratio was 1:0.2. ${ }^{1} \mathrm{H}-{ }^{1} \mathrm{H}$ COSY allowed the assignments of the signals of the protons on the sugar moiety. The signals of $\mathrm{H}_{3}$, in the major and minor conformers (4.72 and $4.81 \mathrm{ppm}$, respectively) are pseudo triplets with coupling constants $J=3.1$ and $2.5 \mathrm{~Hz}$, respectively, which are consistent with an axial-equatorial coupling. Moreover, in DMSO, the signals of $\mathrm{H}_{3}$, (pseudo triplet) shows only<smiles></smiles>

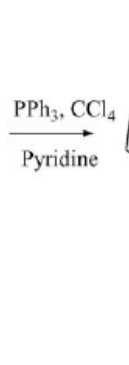

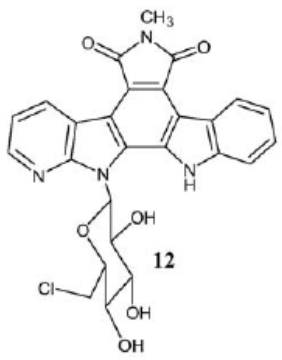

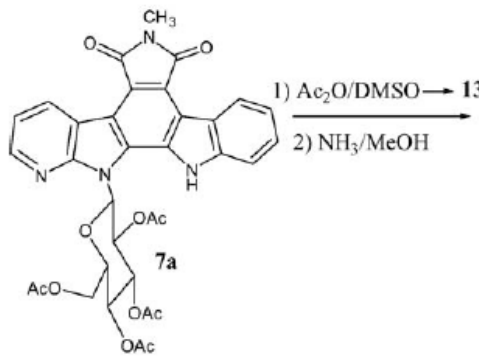<smiles>CC(O)C(O)CC(O)(CC(O)CO)n1c2ncccc2c2c3[nH]c4cc([N+](=O)[O-])ccc4c3c3c(c21)C(=O)N(C)C3=O</smiles>

Scheme 2. Preparation of compounds $\mathbf{1 2}$ and $\mathbf{1 3 .}$ 

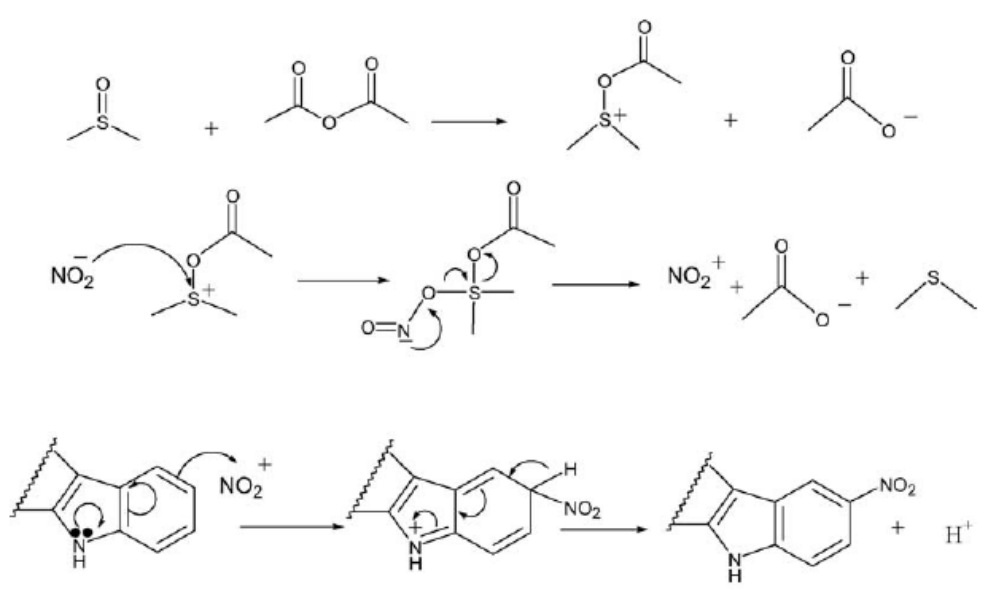

Scheme 3. Proposed mechanism for the nitration in 3 position of compound 13a.

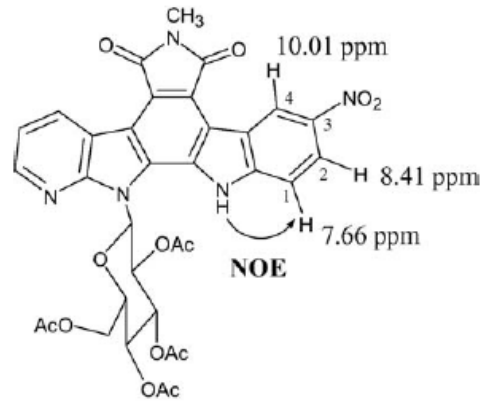

13a

Fig. 2. NMR data for the determination of the structure of compound 13a.

coupling with $\mathrm{H}_{2}$, and $\mathrm{H}_{4}$, which confirms the absence of a hydroxyl group at $\mathrm{C}_{3^{\prime}}$.

Nucleophilic substitution on compound 14 using sodium azide led to the $6^{\prime}$-azido derivative $\mathbf{1 7}$ (Scheme 4) as a mixture of conformers. The ratio of the conformers determined from ${ }^{1} \mathrm{H}$ NMR spectrum in DMSO on the signals of $\mathrm{H}_{1}$, (6.40 and $6.60 \mathrm{ppm}$ ) was 1:1. Iodo derivative $\mathbf{1 6}$ was obtained from chloro compound $\mathbf{1 4}$ via halogen exchange using sodium iodide in acetone. The conformers ratio determined from $\mathrm{H}_{1}$, protons at 6.45 and $6.61 \mathrm{ppm}$ was $1: 4.5$. The iodo compound 20, substituted on the nitrogen of the six-membered ring, also showed conformers. The ratio of these conformers, determined from the ${ }^{1} \mathrm{H}$ NMR spectrum in DMSO on the signals of $\mathrm{H}_{1^{\prime}}(7.83$ and $7.87 \mathrm{ppm})$, was also 1:4.5. A Clemmensen reduction of $\mathbf{5}$ using zinc amalgam afforded $\mathbf{1 9}$ as a mixture of regioisomers in the 1:1 ratio, the regioisomeric ratio being determined from ${ }^{1} \mathrm{H}$ NMR spectrum on the signals at 9.41 and $9.51 \mathrm{ppm}$.

\subsection{In vitro antiproliferative activities}

The cytotoxicities of compounds $\mathbf{8}$-20 were evaluated toward four tumor cell lines: one murine leukemia L1210 and three human tumor cell lines (prostate carcinoma DU145, colon carcinoma HT29, and non-small cell lung carcinoma A549) and compared to those of rebeccamycin and parent

non-aza (1-3) and aza compounds (4-7). The results $\left(\mathrm{IC}_{50}\right.$ values in $\mu \mathrm{M})$ are reported in Table 1. Compared with unsubstituted compound $\mathbf{6}$, with the sugar part attached to the azaindole, the parent anhydride $\mathbf{8}$ was less cytotoxic except on HT29 cells, $N$-amino 9 exhibited a similar profile of cytotoxicity, $N$-diethylaminoethyl $\mathbf{1 1}$ was much more cytotoxic toward HT29 cells but less efficient against DU145 cells. Substitution at the imide nitrogen with a hydroxy group (compound 10) enhanced moderately the cytotoxicity toward DU145 cells but strongly toward HT29 cells. Substitution at $6^{\prime}$ position with a chloro group on the sugar unit or at

Table 1

In vitro antiproliferative activities $\left(\mathrm{IC}_{50}\right.$ in $\left.\mu \mathrm{M}\right)$ toward four tumor cell lines: one murine leukemia L1210, and three human tumors prostate carcinoma DU145, colon carcinoma HT29, non-small cell lung carcinoma A549. Effect on the cell cycle of L1210 cells: percentage of L1210 cells recovered in the $\mathrm{G} 2+\mathrm{M}$ phases (at the indicated drug concentration)

\begin{tabular}{|c|c|c|c|c|c|}
\hline Cpd & L1210 & $\begin{array}{c}\% \text { of L1210 cells in the } \\
\text { G2 + M phase }{ }^{a}\end{array}$ & DU145 & HT29 & A549 \\
\hline 1 & 0.14 & $69 \%(1 \mu \mathrm{M})$ & ne & 0.3 & 0.3 \\
\hline 2 & 0.11 & $71 \%(1 \mu \mathrm{M})$ & ne & 2.5 & 2 \\
\hline 3 & 0.58 & $69 \%(2.5 \mu \mathrm{M})$ & 0.42 & 0.43 & 0.46 \\
\hline 4 & 0.06 & $78 \%(0.25 \mu \mathrm{M})$ & 0.59 & 4.8 & 5.3 \\
\hline 5 & 1.3 & $58 \%(5 \mu \mathrm{M})$ & 6 & 17.8 & 47.2 \\
\hline 6 & 0.13 & $79 \%(0.5 \mu \mathrm{M})$ & 0.36 & $>100$ & $>100$ \\
\hline 7 & 0.34 & ne & 0.2 & 67.2 & 59.9 \\
\hline 8 & 4.00 & $32 \%(20 \mu \mathrm{M})$ & $>100$ & 3 & $>100$ \\
\hline 9 & 0.10 & $62 \%(0.5 \mu \mathrm{M})$ & 0.4 & 33.4 & 77 \\
\hline 10 & 0.37 & $76 \%(2 \mu \mathrm{M})$ & 1.6 & 0.71 & 60.2 \\
\hline 11 & 1.3 & Inactive at $10 \mu \mathrm{M}$ & 7.2 & 0.7 & 31.2 \\
\hline 12 & 0.8 & $28 \%(5 \mu \mathrm{M})$ & 7.9 & 0.9 & 10.8 \\
\hline 13 & 2.4 & ne & 7.2 & 21.4 & $>50$ \\
\hline 14 & 1.4 & $76 \%(5 \mu \mathrm{M})$ & 1.6 & 2.2 & 3.7 \\
\hline 15 & 1.0 & $81 \%(5 \mu \mathrm{M})$ & 1 & 1.1 & 0.71 \\
\hline 16 & 1.2 & $44 \%(20 \mu \mathrm{M})$ & 1.7 & 2.7 & 4.7 \\
\hline 17 & 1.70 & $73 \%(5 \mu \mathrm{M})$ & 1.9 & 2.8 & ne \\
\hline 18 & 1.20 & $67 \%(10 \mu \mathrm{M})$ & 3.5 & 4.8 & 11.2 \\
\hline 19 & 27.1 & ne & 88.8 & 96 & $>100$ \\
\hline 20 & 4.4 & $44 \%(20 \mu \mathrm{M})$ & 6.3 & 7.1 & 17.4 \\
\hline
\end{tabular}



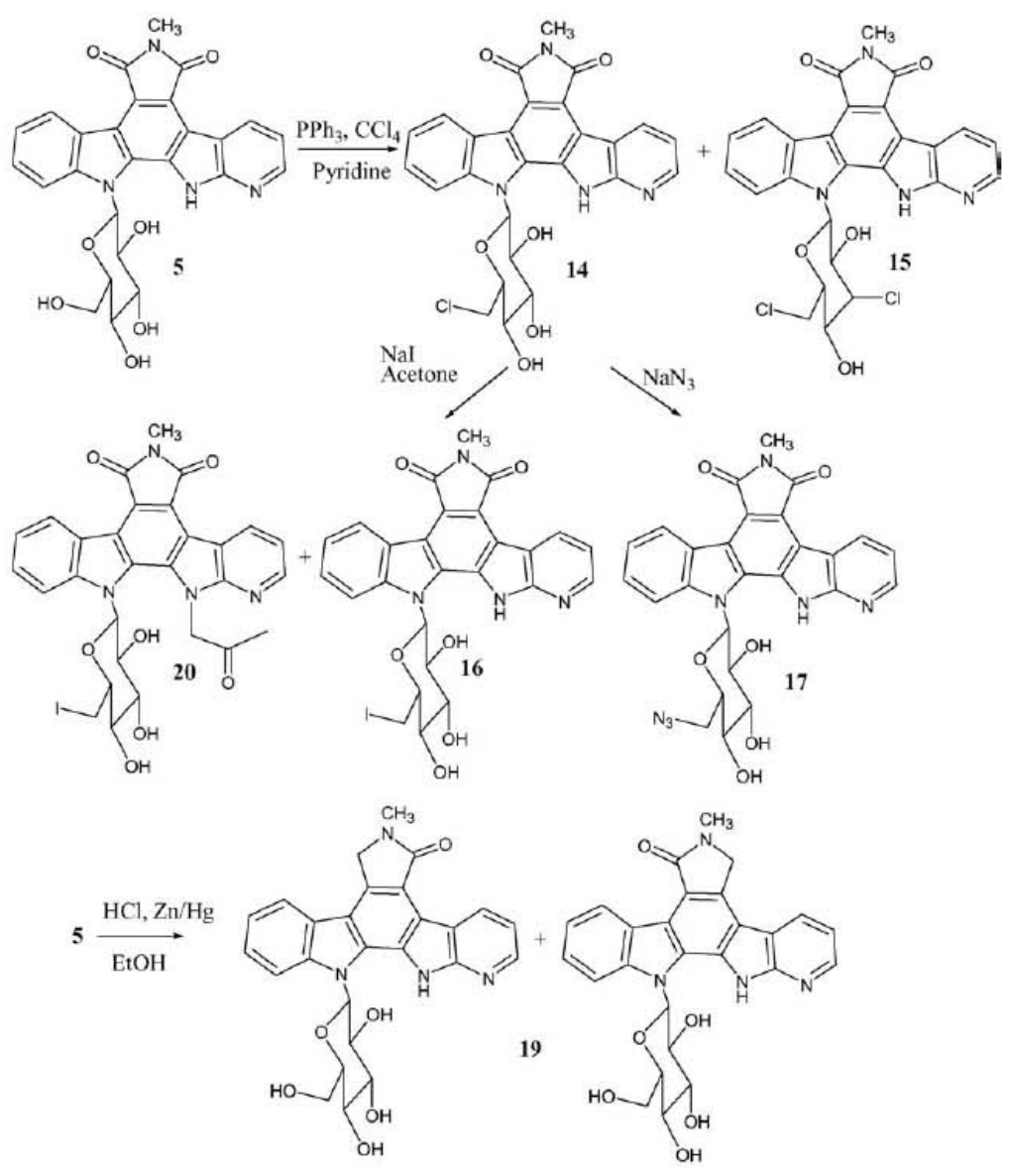

Scheme 4. Synthetic scheme for compounds 14-17, 19 and 20.

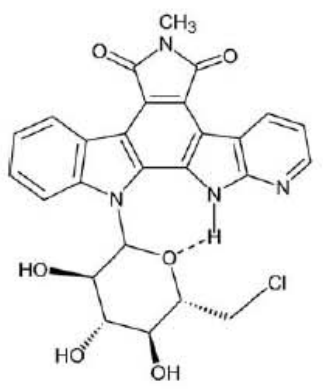

14 "closed conformation"

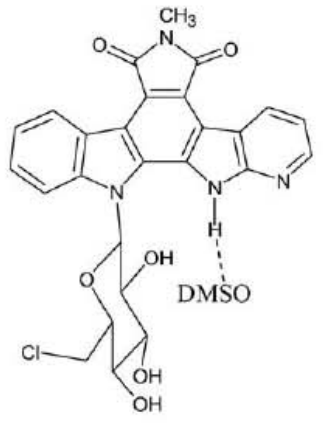

14 "open conformation"

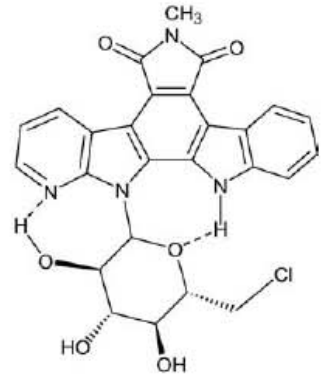

12 "closed conformation"

Fig. 3. Possible "open" or "closed" conformations with compounds 12 and 14

3-position on the indolocarbazole framework with a nitro group weakened the cytotoxicity toward L1210 and DU145 cells (compare 7 with compounds 12 and 13) but enhanced the cytotoxicity against HT29 cells. For compounds with the sugar part linked to the indole moiety, substitutions at $6^{\prime}$ position on the carbohydrate increased the cytotoxicity against DU145, but especially toward HT29 and A549 cells (compare 5 with 14, 16 and 17). The $3^{\prime}, 6^{\prime}$ dichloro compound $\mathbf{1 5}$ was a little bit more efficient than the monochloro compound 14. Compared with the parent compound 16, the introduction of an acetyl group on the nitrogen of the 6-membered ring heterocycle (compound 20 ) decreased the cytotoxicity toward all the cell lines tested. Concerning the regioisomeric mixture of lactams, the replacement of an indole moiety by a 7 -azaindole almost abolished the cytotoxicity against the tumor cell lines tested (compare 18 and 19). In all series, the least sensitive cells are A549 cells except with $3^{\prime}, 6^{\prime}$-dichloro compound $\mathbf{1 5}$. Typical curves of inhibi- 


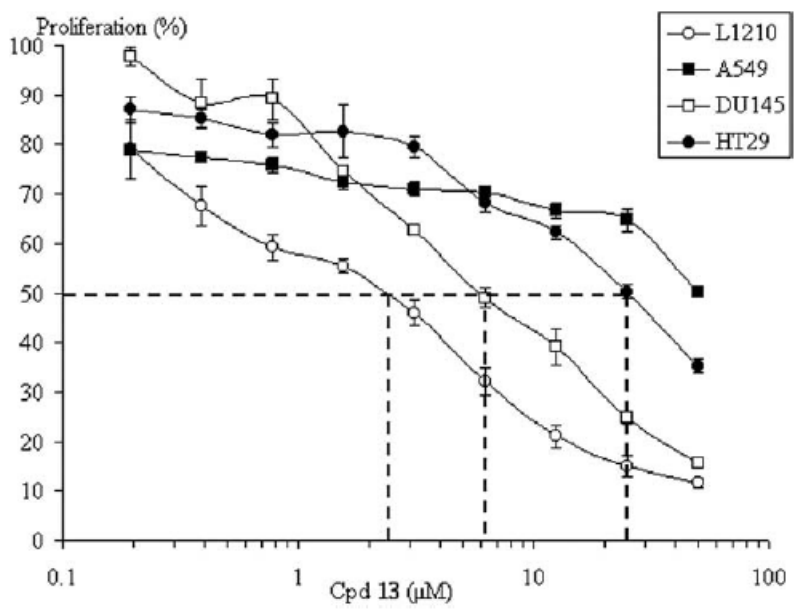

Fig. 4. Typical curves of inhibition of proliferation induced by compound 13.

tion of proliferation induced by compound $\mathbf{1 3}$ are shown on Fig. 4. These results, representative of 3 experiments, clearly show that compound $\mathbf{1 3}$ is less potent to inhibit the proliferation of HT29 and A549 cells than that of L1210 and DU145 cells.

The effect on the cell cycle of L1210 cells was examined. All the compounds tested induced an accumulation of the cells in the $\mathrm{G} 2+\mathrm{M}$ phases compatible with topoisomerase I inhibition but also with a possible inhibition of the enzymes involved in these phases of the cell cycle. Compared with unsubstituted 7-aza compounds $\mathbf{4}$ and $\mathbf{6}$, substitutions at either the imide nitogen or the $6^{\prime}$-position on the sugar moiety strongly decreased the accumulation of the cells in the G2 + M phases, except for the $N$-amino compound 9.

\subsection{Conclusion}

In conclusion, two series of 7-aza rebeccamycin analogues have been synthesized in which the sugar part is linked either to the indole moiety or to the 7-azaindole unit. The cytotoxicities of these new compounds toward the four tumor cell lines tested showed that, compared with the parent compounds, the substitutions and the functional modifications carried out in this work are not generally detrimental to the in vitro antiproliferative activities (except for anhydride $\mathbf{8}$ and lactams 19). Concerning the anhydride $\mathbf{8}$, that is not surprising since we have previously observed in non-aza series that an anhydride function in the upper heterocycle strongly decreased the biological activity [15,17]. The inefficiency of lactams $\mathbf{1 9}$ is more surprising since the non-aza regioisomeric mixture of lactams $\mathbf{1 8}$ is much more cytotoxic than $\mathbf{1 9}$. Lactams 18 were found to have several biological targets including topoisomerase I and protein kinase C [18]. The nitrogen atom of the 7-azaindole seem, at first sight, to abolish the inhibitory potencies toward the target enzymes whereas it is not the case for the other aza-compounds studied. The inhibitory potencies of lactams $\mathbf{1 9}$ toward topoisomerase I and $\mathrm{PKC}$ have now to be determined. We have shown in pre- vious studies that, for compounds bearing one 7-azaindole unit, when the sugar part was linked to the indole moiety, the affinity for DNA and topoisomerase I inhibition were highly enhanced compared with the non-aza parent compounds whereas, when the sugar was attached to the azaindole, the affinity for DNA and topoisomerase I inhibition were highly decreased. However, in both series, strongly cytotoxic compounds toward some tumor cell lines could be found, probably due to the activity toward other targets than DNA and topoisomerase I for the compounds having the carbohydrate linked to the 7 -azaindole moiety. Identical results are obtained with the newly synthesized products. For example, no significant differences were observed between the cytotoxicities of the $6^{\prime}$-chloro derivatives $\mathbf{1 2}$ and $\mathbf{1 4}$. It could be possible that topoisomerase I and/or some kinases, that could be targets for these aza rebeccamycins, are over-expressed in the most sensitive tumor cells. It is well known that topoisomerase I and kinases are not expressed similarly in the different tumor cell lines [19-21]. Or if topoisomerase I is the main target, it is also well known that DNA repair mechanisms can be disturbed in some tumor cell lines due to mutations of proteins involved in DNA repair [22,23].

Of the tumor cell lines tested, non-small cell lung carcinoma A549 are the least sensitive cells to the 7-aza rebeccamycin analogues.

\section{Experimental protocols}

IR spectra were recorded on a Perkin-Elmer 881 spectrometer $\left(v\right.$ in $\left.\mathrm{cm}^{-1}\right)$. NMR spectra were performed on a Bruker AC $400\left({ }^{1} \mathrm{H}: 400 \mathrm{MHz},{ }^{13} \mathrm{C}: 100 \mathrm{MHz}\right.$ ) (chemical shifts $\delta$ in ppm, the following abbreviations are used: singlet (s), broad singlet (br s), doublet (d), doubled doublet (dd), triplet (t), pseudo triplet (pt), multiplet $(\mathrm{m})$, tertiary carbons $(\mathrm{C}$ tert), quaternary carbons (C quat). Mass spectra $(\mathrm{FAB}+$ ) were determined at CESAMO (Talence, France) on a high resolution Fisons Autospec-Q spectrometer. Mass spectra (ESI+) were determined in our laboratory on a MS Hewlett Packard spectrometer. Chromatographic purifications were performed by flash silicagel Geduran SI 60 (Merck) $0.040-0.063 \mathrm{~mm}$ column chromatography.

\subsection{2,5-dihydro-3-(1H-indol-3-yl)-4-[1-( $\beta$-D-glucopyra- nos 1-yl)-pyrrolo[2,3-b]pyridin-3-yl]-furane-2,5-dione $(B)$}

To a suspension of $\mathbf{A}(314.8 \mathrm{mg}, 0.468 \mathrm{mmol})$ in water $(40 \mathrm{ml})$ was added $\mathrm{NaOH}(280 \mathrm{mg}, 7 \mathrm{mmol})$ and THF $(30 \mathrm{ml})$. After stirring for $1 \mathrm{~h} 30$ at room temperature, the mixture was acidified to $\mathrm{pH} 1$ with $2 \mathrm{~N} \mathrm{HCl}$ and stirred for $30 \mathrm{~min}$. Water was added. After extraction with EtOAc, the organic phase was dried over $\mathrm{MgSO}_{4}$ and the solvent was removed. The residue was purified by flash chromatography (eluent: EtOAc/MeOH 95:5) to afford B (137 mg, $0.279 \mathrm{mmol}, 60 \%$ yield) as a red solid.

M.p. $182-183^{\circ} \mathrm{C}$. 
IR $(\mathrm{KBr}), v_{\mathrm{C}=\mathrm{O}} 1755,1820 \mathrm{~cm}^{-1}, v_{\mathrm{NH}, \mathrm{OH}} 3000-3600 \mathrm{~cm}^{-1}$. HRMS (FAB+) $[\mathrm{M}+\mathrm{H}]^{+}$calcd for $\mathrm{C}_{25} \mathrm{H}_{22} \mathrm{~N}_{3} \mathrm{O}_{8} 492.1407$, found 492.1412 .

${ }^{1} \mathrm{H}$ NMR (400 MHz, DMSO- $d_{6}$ ): 3.28-3.57 (4H, m), 3.75 $\left(1 \mathrm{H}, \mathrm{dd}, J_{1}=10.0 \mathrm{~Hz}, J_{2}=4.5 \mathrm{~Hz}\right), 3.85(1 \mathrm{H}, \mathrm{m}), 4.64(1 \mathrm{H}$, $\mathrm{t}, J=6.5 \mathrm{~Hz}, \mathrm{OH}), 5.19(1 \mathrm{H}, \mathrm{d}, J=5.0 \mathrm{~Hz}, \mathrm{OH}), 5.28(1 \mathrm{H}, \mathrm{br}$ $\mathrm{s}, \mathrm{OH}), 5.32(1 \mathrm{H}, \mathrm{d}, J=6.0 \mathrm{~Hz}, \mathrm{OH}), 5.88(1 \mathrm{H}, \mathrm{d}, J=9.5 \mathrm{~Hz}$, $\left.\mathrm{H}_{1}\right), 6.79(1 \mathrm{H}, \mathrm{t}, J=8.0 \mathrm{~Hz}), 6.84\left(1 \mathrm{H}, \mathrm{dd}, J_{1}=8.0 \mathrm{~Hz}\right.$, $\left.J_{2}=5.0 \mathrm{~Hz}\right), 6.98(1 \mathrm{H}, \mathrm{d}, J=8.0 \mathrm{~Hz}), 7.09(2 \mathrm{H}, \mathrm{m}), 7.46$ $(1 \mathrm{H}, \mathrm{d}, J=8.0 \mathrm{~Hz}), 7.93(1 \mathrm{H}, \mathrm{s}), 8.20(1 \mathrm{H}, \mathrm{s}), 8.21(1 \mathrm{H}, \mathrm{d}$, $J=10.0 \mathrm{~Hz}), 12.10\left(1 \mathrm{H}, \mathrm{s}, \mathrm{NH}_{\text {ind }}\right)$.

${ }^{13} \mathrm{C}$ NMR (100 MHz, DMSO- $\left.d_{6}\right): 60.9\left(\mathrm{C}_{6^{\prime}}\right), 69.9,72.0$, 77.4, 80.0, 82.4 $\left(\mathrm{C}_{1^{\prime}}, \mathrm{C}_{2^{\prime}}, \mathrm{C}_{3^{\prime}}, \mathrm{C}_{4^{\prime}}, \mathrm{C}_{5^{\prime}}\right), 112.1,116.8,120.3$, 121.2, 122.3, 129.5, 130.3, 131.0, 143.4 (C tert arom), 104.1, 104.6, 117.9, 124.9, 126.0, 130.3, 136.1, 147.6 (C quat arom), $166.1,166.2(\mathrm{C}=\mathrm{O})$.

\subsection{3-( $\beta$-D-Glucopyranos-1-yl)-5,7-dihydro-12H-} pyrido $\left[3^{\prime}, 2^{\prime}: 4,5\right]$ pyrrolo[2,3-a]furo[3,4-c]carbazole-5,7dione ( 8 )

To a solution of $\mathbf{B}(137 \mathrm{mg}, 0.279 \mathrm{mmol})$ in acetonitrile $(300 \mathrm{ml})$ was added iodine $(532 \mathrm{mg}, 2.10 \mathrm{mmol})$. The mixture was irradiated for $4 \mathrm{~h}$ with a medium-pressure mercury lamp $400 \mathrm{~W}$. The solvent was removed. The residue was dissolved in EtOAc $(250 \mathrm{ml})$, washed with saturated aqueous sodium thiosulfate $(100 \mathrm{ml})$ then with brine. After removal of the solvent, methanol was added to the residue which was filtered off. The solid was washed with EtOAc. Compound $\mathbf{8}$ (95 mg, $0.194 \mathrm{mmol}, 70 \%$ yield) was obtained as an orange solid.

M.p. $>300^{\circ} \mathrm{C}$.

IR (KBr) $v_{\mathrm{C}=\mathrm{O}} 1825,1755 \mathrm{~cm}^{-1}, v_{\mathrm{NH}, \mathrm{OH}} 3200-3600 \mathrm{~cm}^{-1}$. HRMS (FAB+) $[\mathrm{M}+\mathrm{H}]^{+}$calcd for $\mathrm{C}_{25} \mathrm{H}_{20} \mathrm{~N}_{3} \mathrm{O}_{8} 490.1250$, found 490.1254 .

${ }^{1} \mathrm{H}$ NMR (400 MHz, DMSO- $\left.d_{6}\right): 3.50-3.60(2 \mathrm{H}, \mathrm{m}), 3.88$ $(1 \mathrm{H}, \mathrm{d}, J=10.5 \mathrm{~Hz}), 3.98-4.07(2 \mathrm{H}, \mathrm{m}), 4.13(1 \mathrm{H}, \mathrm{d}$, $J=9.0 \mathrm{~Hz}), 5.00(1 \mathrm{H}, \mathrm{d}, J=5.0 \mathrm{~Hz}, \mathrm{OH}), 5.23(1 \mathrm{H}, \mathrm{d}$, $J=5.5 \mathrm{~Hz}, \mathrm{OH}), 5.44(1 \mathrm{H}, \mathrm{d}, J=4.7 \mathrm{~Hz}, \mathrm{OH}), 6.19(1 \mathrm{H}, \mathrm{s})$, $6.70\left(1 \mathrm{H}, \mathrm{d}, J=9.0 \mathrm{~Hz}, \mathrm{H}_{1^{\prime}}\right), 7.51(1 \mathrm{H}, \mathrm{t}, J=7.5 \mathrm{~Hz}), 7.60$ $\left(1 \mathrm{H}, \mathrm{dd}, J_{1}=7.0 \mathrm{~Hz}, J_{2}=4.5 \mathrm{~Hz}\right), 7.72(1 \mathrm{H}, \mathrm{t}, J=7.2 \mathrm{~Hz})$, $7.83(1 \mathrm{H}, \mathrm{d}, J=8.5 \mathrm{~Hz}), 8.75(1 \mathrm{H}, \mathrm{d}, J=4.5 \mathrm{~Hz}), 8.96(1 \mathrm{H}$, $\mathrm{d}, J=8.0 \mathrm{~Hz}), 9.23\left(1 \mathrm{H}, \mathrm{dd}, J_{1}=6.5 \mathrm{~Hz}, J_{2}=1.5 \mathrm{~Hz}\right), 11.97$ $\left(1 \mathrm{H}, \mathrm{s}, \mathrm{NH}_{\text {ind }}\right)$.

${ }^{13} \mathrm{C}$ NMR (100 MHz, DMSO- $\left.d_{6}\right): 58.3\left(\mathrm{C}_{6}\right), 67.6,72.8$, 76.4, 78.8, 83.1 $\left(\mathrm{C}_{1^{\prime}}, \mathrm{C}_{2^{\prime}}, \mathrm{C}_{3^{\prime}}, \mathrm{C}_{4^{\prime}}, \mathrm{C}_{5^{\prime}}\right), 112.7,118.0,121.3$, 123.6, 128.0, 132.1, 147.8 (C tert arom), 113.7, 115.6, 116.7, 117.8, 117.9, 119.7, 120.8, 130.3, 140.9, 152.2 (C quat arom), $164.4,164.5(\mathrm{C}=\mathrm{O})$.

\subsection{6-Amino-13-( $\beta$-D-glucopyranos-1-yl)-5,7-dihydro- 12 H-pyrido $\left[3^{\prime}, 2^{\prime}: 4,5\right]$ pyrrolo $[2,3-a]$ pyrrolo[3,4- c]carbazole-5,7-dione (9)}

A mixture of anhydride 8 (20 $\mathrm{mg}, 0.041 \mathrm{mmol})$ and hydrazine hydrate $(384 \mu \mathrm{l})$ was stirred at room temperature for $24 \mathrm{~h}$ at $60{ }^{\circ} \mathrm{C}$. Water $(15 \mathrm{ml})$ then $1 \mathrm{~N} \mathrm{HCl}(20 \mathrm{ml})$ were added The precipitate was filtered off and washed with water to give compound 9 (16 mg, $0.0318 \mathrm{mmol}, 78 \%$ yield) as a yellow solid.

M.p. $>300^{\circ} \mathrm{C}$

IR $(\mathrm{KBr}) v_{\mathrm{C}=\mathrm{O}} 1700,1750 \mathrm{~cm}^{-1}, v_{\mathrm{NH}} 3320 \mathrm{~cm}^{-1}, v_{\mathrm{OH}}$ $3500 \mathrm{~cm}^{-1}$.

HRMS (FAB+) $[\mathrm{M}+\mathrm{H}]^{+}$calcd for $\mathrm{C}_{25} \mathrm{H}_{22} \mathrm{~N}_{5} \mathrm{O}_{7} 504.1519$, found 504.1513 .

${ }^{1} \mathrm{H}$ NMR (400 MHz, DMSO- $\left.d_{6}\right): 3.58(2 \mathrm{H}, \mathrm{br} \mathrm{s}), 3.86(1 \mathrm{H}$, d, $J=9.5 \mathrm{~Hz}), 3.94(1 \mathrm{H}, \mathrm{d}, J=9.5 \mathrm{~Hz}), 4.02(1 \mathrm{H}$, br s $), 4.11$ $(1 \mathrm{H}, \mathrm{d}, J=10.5 \mathrm{~Hz}), 4.99(1 \mathrm{H}, \mathrm{s}, \mathrm{OH}), 5.06\left(2 \mathrm{H}, \mathrm{s}, \mathrm{NH}_{2}\right)$, $5.22(1 \mathrm{H}, \mathrm{s}, \mathrm{OH}), 5.48(1 \mathrm{H}, \mathrm{s}, \mathrm{OH}), 6.15(1 \mathrm{H}, \mathrm{s}, \mathrm{OH}), 6.64$ $\left(1 \mathrm{H}, \mathrm{d}, J=5.5 \mathrm{~Hz}, \mathrm{H}_{1^{\prime}}\right), 7.44(1 \mathrm{H}, \mathrm{t}, J=7.0 \mathrm{~Hz}), 7.54(1 \mathrm{H}, \mathrm{t}$, $J=5.5 \mathrm{~Hz}), 7.64(1 \mathrm{H}, \mathrm{t}, J=7.0 \mathrm{~Hz}), 7.76(1 \mathrm{H}, \mathrm{d}, J=8.0 \mathrm{~Hz})$, $8.67(1 \mathrm{H}, \mathrm{d}, J=4.0 \mathrm{~Hz}), 9.13(1 \mathrm{H}, \mathrm{d}, J=8.0 \mathrm{~Hz}), 9.38(1 \mathrm{H}$, $\mathrm{d}, J=7.5 \mathrm{~Hz}), 11.71\left(1 \mathrm{H}, \mathrm{s}, \mathrm{NH}_{\text {ind }}\right)$.

${ }^{13} \mathrm{C}$ NMR (100 MHz, DMSO- $\left.d_{6}\right): 58.3\left(\mathrm{C}_{6^{\prime}}\right), 67.6,72.7$, 76.5, 78.7, 83.0 $\left(\mathrm{C}_{1^{\prime}}, \mathrm{C}_{2^{\prime}}, \mathrm{C}_{3^{\prime}}, \mathrm{C}_{4^{\prime}}, \mathrm{C}_{5^{\prime}}\right), 112.3,117.4,120.7$ 124.4, 127.5, 132.7, 147.1 (C tert arom), 114.2, 115.3, 117.1, 117.7, 118.7, 121.2, 127.3, 129.5, 141.1, 152.4 (C quat arom), $168.6(2 \mathrm{C}, \mathrm{C}=\mathrm{O})$.

3.4. 6-Hydroxy-13-( $\beta$-D-glucopyranos-1-yl)-5,7-dihydro$12 \mathrm{H}$-pyrido[3',2':4,5]pyrrolo[2,3-a] pyrrolo[3,4-c]carbazole-5,7-dione (10)

To a solution of $\mathbf{8}(20 \mathrm{mg}, 0.041 \mathrm{mmol})$ in DMF $(1 \mathrm{ml})$ was added hydroxylamine hydrochloride (197.4 mg, $2.84 \mathrm{mmol})$ then triethylamine $(394 \mu \mathrm{l}, 2.84 \mathrm{mmol})$. The mixture was stirred at $70{ }^{\circ} \mathrm{C}$ for $24 \mathrm{~h}$. After addition of $1 \mathrm{~N} \mathrm{HCl}$ $(20 \mathrm{ml})$, EtOAc and THF were added. The organic phase was successively washed with saturated aqueous $\mathrm{NaHCO}_{3}$ and brine, then dried with $\mathrm{MgSO}_{4}$

The solvent was removed to afford $10(10 \mathrm{mg}, 0.020 \mathrm{mmol}$, $48 \%$ yield) as a yellow-orange solid.

M.p. $>300{ }^{\circ} \mathrm{C}$.

$\operatorname{IR}(\mathrm{KBr}) v_{\mathrm{C}=\mathrm{O}} 1700,1750 \mathrm{~cm}^{-1}, v_{\mathrm{NH}} 3320 \mathrm{~cm}^{-1}, v_{\mathrm{OH}}$ $3460 \mathrm{~cm}^{-1}$.

HRMS (FAB+) $[\mathrm{M}+\mathrm{H}]^{+}$calcd for $\mathrm{C}_{25} \mathrm{H}_{21} \mathrm{~N}_{4} \mathrm{O}_{8} 505.1359$, found 505.1360 .

${ }^{1} \mathrm{H}$ NMR (400 MHz, DMSO- $\left.d_{6}\right): 3.50-3.60(2 \mathrm{H}, \mathrm{m}), 3.82$ $(1 \mathrm{H}, \mathrm{d}, J=10.0 \mathrm{~Hz}), 3.91(1 \mathrm{H}, \mathrm{d}, J=12.0 \mathrm{~Hz}), 3.96(1 \mathrm{H}, \mathrm{m})$, $4.08(1 \mathrm{H}, \mathrm{d}, J=10.0 \mathrm{~Hz}), 4.94(1 \mathrm{H}, \mathrm{br} \mathrm{s}, \mathrm{OH}), 5.08-5.50$ $(2 \mathrm{H}$, br s, $2 \mathrm{OH}), 6.08(1 \mathrm{H}$, br s, OH $), 6.60(1 \mathrm{H}, \mathrm{d}, J=8.0 \mathrm{~Hz}$, $\left.\mathrm{H}_{1^{\prime}}\right), 7.42(1 \mathrm{H}, \mathrm{t}, J=8.0 \mathrm{~Hz}), 7.51\left(1 \mathrm{H}, \mathrm{dd}, J_{1}=8.0 \mathrm{~Hz}\right.$, $\left.J_{2}=5.0 \mathrm{~Hz}\right), 7.62(1 \mathrm{H}, \mathrm{t}, J=7.0 \mathrm{~Hz}), 7.72(1 \mathrm{H}, \mathrm{d}, J=8.0 \mathrm{~Hz})$, $8.65(1 \mathrm{H}, \mathrm{d}, J=3.0 \mathrm{~Hz}), 9.05(1 \mathrm{H}, \mathrm{d}, J=8.0 \mathrm{~Hz}), 9.30(1 \mathrm{H}$, d, $J=7.5 \mathrm{~Hz}), 10.75(1 \mathrm{H}, \mathrm{s}, \mathrm{N}-\mathrm{OH}), 11.71\left(1 \mathrm{H}, \mathrm{s}, \mathrm{NH}_{\text {ind }}\right)$.

${ }^{13} \mathrm{C}$ NMR $\left(100 \mathrm{MHz}\right.$, DMSO- $\left.d_{6}\right): 56.2\left(\mathrm{C}_{6^{\prime}}\right), 65.5,70.6$, 74.2, 76.6, 80.9 $\left(\mathrm{C}_{1^{\prime}}, \mathrm{C}_{2^{\prime}}, \mathrm{C}_{3^{\prime}}, \mathrm{C}_{4^{\prime}}, \mathrm{C}_{5^{\prime}}\right), 110.3,115.6,122.3$, 123.9, 128.3, 130.8, 145.4 (C tert arom), 112.0, 113.4, 113.5, 115.2, 115.9, 125.3, 127.5, 137.6, 138.9, 150.4 (C quat arom), 164.4, 164.0 $(\mathrm{C}=\mathrm{O})$. 
3.5. 6-Diethylaminoethyl-13-( $\beta$-D-glucopyranos-1-yl)-5,7dihydro-12H-pyrido $\left[3^{\prime}, 2^{\prime}: 4,5\right]$ pyrrolo[2,3-a] pyrrolo[3,4c]carbazole-5,7-dione hydrochloride (11)

To a solution of anhydride $8(50 \mathrm{mg}, 0.102 \mathrm{mmol})$ in THF (6 ml) was added $N, N$-diethylethylenediamine (22 $\mu$, $0.153 \mathrm{mmol}$ ). The light-protected mixture was refluxed for 5 days. After cooling, $1 \mathrm{~N} \mathrm{HCl}(40 \mathrm{ml})$ was added and the mixture was extracted with EtOAc.

EtOAc was added to the aqueous phases and the $\mathrm{pH}$ was adjusted to $\mathrm{pH} 12$ by addition of saturated aqueous solution of $\mathrm{NaHCO}_{3}$. After extraction with EtOAc, the organic phase was dried over $\mathrm{MgSO}_{4}$ and the solvent was removed under reduced pressure at room temperature to give the amine $(110 \mathrm{mg})$ as a yellow solid.

To a solution of the amine in methanol $(500 \mu \mathrm{l})$ at $0{ }^{\circ} \mathrm{C} 1 \mathrm{~N}$ $\mathrm{HCl}(200 \mu \mathrm{l})$ was added dropwise. The mixture was stirred for $30 \mathrm{~min}$ at room temperature. The solvent was removed to afford hydrochloride 11 (60.7 mg, $0.097 \mathrm{mmol}, 95 \%$ yield) as an orange solid.

M.p. $>300^{\circ} \mathrm{C}$

$\operatorname{IR}(\mathrm{KBr}) v_{\mathrm{C}=\mathrm{O}} 1700,1751 \mathrm{~cm}^{-1}, v_{\mathrm{NH}, \mathrm{OH}} 3120-3650 \mathrm{~cm}^{-1}$. HRMS (FAB+) $[\mathrm{M}+\mathrm{H}]^{+}$calcd for $\mathrm{C}_{31} \mathrm{H}_{34} \mathrm{~N}_{5} \mathrm{O}_{7} 588.2458$, found 588.2461 .

${ }^{1} \mathrm{H}$ NMR (400 MHz, DMSO- $\left.d_{6}\right): 1.32(6 \mathrm{H}, \mathrm{t}, J=7.0 \mathrm{~Hz})$, $3.25-3.36(4 \mathrm{H}, \mathrm{m}), 3.44-3.66(4 \mathrm{H}, \mathrm{m}), 3.84(1 \mathrm{H}, \mathrm{d}$, $J=10.0 \mathrm{~Hz}), 3.94(1 \mathrm{H}, \mathrm{d}, J=9.5 \mathrm{~Hz}), 4.04(1 \mathrm{H}, \mathrm{t}, J=9.0 \mathrm{~Hz})$, $4.10-4.22(2 \mathrm{H}, \mathrm{m}), 4.52-5.20(4 \mathrm{H}, \mathrm{m}, 4 \mathrm{OH}), 6.64(1 \mathrm{H}, \mathrm{d}$, $\left.J=9.0 \mathrm{~Hz}, \mathrm{H}_{1}\right), 7.44(1 \mathrm{H}, \mathrm{t}, J=7.0 \mathrm{~Hz}), 7.53(1 \mathrm{H}, \mathrm{dd}$, $\left.J_{1}=7.0 \mathrm{~Hz}, J_{2}=5.0 \mathrm{~Hz}\right), 7.64(1 \mathrm{H}, \mathrm{t}, J=7.5 \mathrm{~Hz}), 7.79(1 \mathrm{H}$, d, $J=8.0 \mathrm{~Hz}), 8.68(1 \mathrm{H}, \mathrm{d}, J=3.5 \mathrm{~Hz}), 9.10(1 \mathrm{H}, \mathrm{d}, J=$ $8.0 \mathrm{~Hz}), 9.34(1 \mathrm{H}, \mathrm{d}, J=8.0 \mathrm{~Hz}), 10.98(1 \mathrm{H}, \mathrm{br} \mathrm{s}, \mathrm{NH}), 11.70$ $\left(1 \mathrm{H}, \mathrm{s}, \mathrm{NH}_{\mathrm{ind}}\right)$.

${ }^{13} \mathrm{C}$ NMR (100 MHz, DMSO- $\left.d_{6}\right): 8.2(2 \mathrm{C})\left(\mathrm{CH}_{3}\right), 32.1$, $46.1(2 \mathrm{C}), 47.8\left(\mathrm{CH}_{2}\right), 58.3\left(\mathrm{C}_{6^{\prime}}\right), 67.5,72.9,76.4,78.9,83.0$ $\left(\mathrm{C}_{1^{\prime}}, \mathrm{C}_{2^{\prime}}, \mathrm{C}_{3^{\prime}}, \mathrm{C}_{4^{\prime}}, \mathrm{C}_{5^{\prime}}\right), 112.4,117.4,120.7,124.3,127.6$, 132.6, 147.2 (C tert arom), 114.1, 115.4, 117.8, 118.9, 120.6, $121.1,127.3,129.5,141.0,152.5$ (C quat arom), 169.1 (2C, $\mathrm{C}=\mathrm{O}$ ).

3.6. 6-Methyl-13-(6-chloro-6-deoxy- $\beta$-D-glucopyranos-1yl)-5,7-dihydro-12H-pyrido[3',2':4,5]pyrrolo[2,3a]pyrrolo[3,4-c]carbazole-5,7-dione (12)

To a solution of compound $7(178 \mathrm{mg}, 0.354 \mathrm{mmol})$ in pyridine $(2.5 \mathrm{ml})$ was added triphenylphosphine $(371 \mathrm{mg}$, $1.42 \mathrm{mmol})$ then $\mathrm{CCl}_{4}(68 \mu \mathrm{l}, 0.698 \mathrm{mmol})$. The mixture was stirred at room temperature for $2 \mathrm{~h} 30$ then poured into water. After extraction with EtOAc, the organic phase was successively washed with $1 \mathrm{~N} \mathrm{HCl}$, water, and saturated aqueous $\mathrm{NaHCO}_{3}$. After removal of the solvent, the residue was purified by flash chromatography (eluent EtOAc) to give $\mathbf{1 2}$ (129 mg, $0.248 \mathrm{mmol}, 70 \%$ yield) as a yellow solid.

M.p. $275-280^{\circ} \mathrm{C}$ (decomposition).

IR (KBr) $v_{\mathrm{C}=\mathrm{O}} 1750,1695 \mathrm{~cm}^{-1}, v_{\mathrm{NH}, \mathrm{OH}} 3100-3600 \mathrm{~cm}^{-1}$.

HRMS $(\mathrm{FAB}+)[\mathrm{M}+\mathrm{H}]^{+}$calcd for $\mathrm{C}_{26} \mathrm{H}_{22} \mathrm{~N}_{4} \mathrm{O}_{6} \mathrm{Cl}$ 521.1227 , found 521.1225 .
${ }^{1} \mathrm{H}$ NMR (400 MHz, DMSO- $\left.d_{6}\right): 3.20\left(3 \mathrm{H}, \mathrm{s}, \mathrm{CH}_{3}\right), 3.63$ $(1 \mathrm{H}, \mathrm{m}), 3.75(1 \mathrm{H}, \mathrm{m}), 3.99(1 \mathrm{H}, \mathrm{m}), 4.29(1 \mathrm{H}, \mathrm{d}, J=12.0 \mathrm{~Hz})$, $4.39(2 \mathrm{H}, \mathrm{d}, J=11.0 \mathrm{~Hz}), 5.14(1 \mathrm{H}, \mathrm{d}, J=4.0 \mathrm{~Hz}, \mathrm{OH}), 5.37$ $(1 \mathrm{H}, \mathrm{d}, J=5.5 \mathrm{~Hz}, \mathrm{OH}), 5.83(1 \mathrm{H}, \mathrm{d}, J=3.0 \mathrm{~Hz}, \mathrm{OH}), 6.71$ $\left(1 \mathrm{H}, \mathrm{d}, J=9.0 \mathrm{~Hz}, \mathrm{H}_{1^{\prime}}\right), 7.45(1 \mathrm{H}, \mathrm{m}), 7.54(1 \mathrm{H}, \mathrm{t}, J=6.0 \mathrm{~Hz})$, $7.60(1 \mathrm{H}, \mathrm{m}), 7.64(1 \mathrm{H}, \mathrm{m}), 8.66(1 \mathrm{H}, \mathrm{d}, J=4.0 \mathrm{~Hz}), 9.08$ $(1 \mathrm{H}, \mathrm{d}, J=7.5 \mathrm{~Hz}), 9.30(1 \mathrm{H}, \mathrm{d}, J=8.0 \mathrm{~Hz}), 10.62(1 \mathrm{H}, \mathrm{s}$, $\mathrm{NH}_{\text {ind }}$ ).

${ }^{13} \mathrm{C}$ NMR $\left(100 \mathrm{MHz}\right.$, DMSO- $\left.d_{6}\right): 23.7\left(\mathrm{NCH}_{3}\right), 45.7\left(\mathrm{C}_{6}\right)$, 69.2, 72.6, 76.8, 77.5, 83.5 $\left(\mathrm{C}_{1^{\prime}}, \mathrm{C}_{2^{\prime}}, \mathrm{C}_{3^{\prime}}, \mathrm{C}_{4^{\prime}}, \mathrm{C}_{5^{\prime}}\right), 111.6$, 117.7, 121.0, 124.6, 127.9, 132.8, 147.2 (C tert arom), 114.2, $115.4,117.6,119.4,121.4$ (2C), 126.7, 129.0, 140.2, 152.4 (C quat arom), $169.3(2 \mathrm{C}, \mathrm{C}=\mathrm{O})$.

3.7. 6-Methyl-9-nitro-13-(2,3,4,6-tetra-O-acetyl- $\beta$-D-glucopyranos-1-yl)-5,7-dihydro- $12 \mathrm{H}$ -

pyrido[ $\left.3^{\prime}, 2^{\prime}: 4,5\right]$ pyrrolo[2,3-a] pyrrolo[3,4-c]carbazole5,7-dione (13a)

To a solution of $\mathrm{KNO}_{2}(38 \mathrm{mg}, 0.447 \mathrm{mmol}, 6 \mathrm{eq})$ in DMSO $(298 \mu \mathrm{l})$ and HMPA $(149 \mu \mathrm{l})$ was added compound $7 \mathbf{a}(50 \mathrm{mg}, 0.074 \mathrm{mmol})$ before dropwise addition of a solution of acetic anhydride $(40 \mu \mathrm{l})$ in DMSO $(298 \mu \mathrm{l})$ and HMPA $(149 \mu \mathrm{l})$. The mixture was stirred at room temperature for 4 days, then hydrolyzed at $0{ }^{\circ} \mathrm{C}$ and extracted with EtOAc. The organic phase was washed with water, dried over $\mathrm{MgSO}_{4}$, and the solvent was removed. The residue was purified by flash chromatography (eluent: EtOAc/cyclohexane from 3:7 to $6: 4)$ to give 13a (12.5 mg, $0.0175 \mathrm{mmol}, 24 \%$ yield) as a yellow solid and unreacted starting product $(28 \mathrm{mg})$.

M.p. $>300{ }^{\circ} \mathrm{C}$.

IR (KBr) $v_{\mathrm{C}=\mathrm{O}} 1700,1750 \mathrm{~cm}^{-1}, v_{\mathrm{NH}} 3200-3600 \mathrm{~cm}^{-1}$.

${ }^{1} \mathrm{H} \mathrm{NMR}\left(400 \mathrm{MHz}, \mathrm{CDCl}_{3}\right): 1.51\left(3 \mathrm{H}, \mathrm{s}, \mathrm{CH}_{3} \mathrm{CO}\right), 1.86$ $\left(3 \mathrm{H}, \mathrm{s}, \mathrm{CH}_{3} \mathrm{CO}\right), 2.09\left(3 \mathrm{H}, \mathrm{s}, \mathrm{CH}_{3} \mathrm{CO}\right), 2.20\left(3 \mathrm{H}, \mathrm{s}, \mathrm{CH}_{3} \mathrm{CO}\right)$, $3.22\left(3 \mathrm{H}, \mathrm{s}, \mathrm{NCH}_{3}\right), 4.37\left(1 \mathrm{H}, \mathrm{dd}, J_{I}=13.0 \mathrm{~Hz}, J_{2}=2.0 \mathrm{~Hz}\right.$, $\left.\mathrm{H}_{6^{\prime}}\right), 4.41\left(1 \mathrm{H}, \mathrm{m}, \mathrm{H}_{5^{\prime}}\right), 4.83\left(1 \mathrm{H}, \mathrm{dd}, J_{1}=13.0 \mathrm{~Hz}, J_{2}=\right.$ $\left.4.0 \mathrm{~Hz}, \mathrm{H}_{6^{\prime}}\right), 5.34\left(1 \mathrm{H}, \mathrm{m}, \mathrm{H}_{2^{\prime}}\right), 5.50-5.57\left(2 \mathrm{H}, \mathrm{m}, \mathrm{H}_{3^{\prime}}, \mathrm{H}_{4^{\prime}}\right)$, $6.88\left(1 \mathrm{H}, \mathrm{d}, J=9.5 \mathrm{~Hz}, \mathrm{H}_{1^{\prime}}\right), 7.37\left(1 \mathrm{H}, \mathrm{dd}, J_{1}=8.0 \mathrm{~Hz}, J_{2}=\right.$ $5.0 \mathrm{~Hz}), 7.66\left(1 \mathrm{H}, \mathrm{d}, J=9.0 \mathrm{~Hz}, \mathrm{H}_{1}\right), 8.41\left(1 \mathrm{H}, \mathrm{dd}, J_{1}=\right.$ $\left.9.0 \mathrm{~Hz}, J_{2}=2.5 \mathrm{~Hz}, \mathrm{H}_{2}\right), 8.57\left(1 \mathrm{H}, \mathrm{dd}, J_{1}=5.0 \mathrm{~Hz}, J_{2}=\right.$ $1.5 \mathrm{~Hz}), 9.31\left(1 \mathrm{H}, \mathrm{dd}, J_{1}=8.0 \mathrm{~Hz}, J_{2}=1.5 \mathrm{~Hz}\right), 10.01(1 \mathrm{H}$, d, $\left.J=2.0 \mathrm{~Hz}, \mathrm{H}_{4}\right), 10.29\left(1 \mathrm{H}, \mathrm{s}, \mathrm{NH}_{\text {ind }}\right)$.

${ }^{13} \mathrm{C}$ NMR $\left(100 \mathrm{MHz}, \mathrm{CDCl}_{3}\right): 19.2,20.5,20.7,21.2$ $\left(\mathrm{CH}_{3} \mathrm{CO}\right), 24.1\left(\mathrm{NCH}_{3}\right), 61.6\left(\mathrm{C}_{6}\right), 67.6,70.5,73.0,76.6$, $82.3\left(\mathrm{C}_{1^{\prime}}, \mathrm{C}_{2^{\prime}}, \mathrm{C}_{3^{\prime}}, \mathrm{C}_{4^{\prime}}, \mathrm{C}_{5^{\prime}}\right), 111.8,118.7,122.7,123.2,134.5$, 147.6 (C tert arom), 115.2, 117.4, 119.3, 121.3, 122.3, 127.5, 130.7, 142.7, 143.9, 152.2 (C quat arom), 168.2, 169.5, 169.6, $169.9,170.7(\mathrm{C}=\mathrm{O})$.

3.8. 6-Methyl-9-nitro-13-( $\beta$-D-glucopyranos-1-yl)-5,7-dihydro-12H-pyrido $\left[3^{\prime}, 2^{\prime}: 4,5\right]$ pyrrolo[2,3-a] pyrrolo[3,4c]carbazole-5,7-dione (13)

To a solution of $\mathrm{MeOH}(2 \mathrm{ml})$ saturated with $\mathrm{NH}_{3}$ was added a solution of 13a (12.5 mg, $0.017 \mathrm{mmol})$ in THF $(2 \mathrm{ml})$. The mixture was stirred at room temperature for $12 \mathrm{~h}$, then 
EtOAc was added. After extraction, the organic phase was washed with water, dried over $\mathrm{MgSO}_{4}$, and the solvent was removed to give $\mathbf{1 3}$ (9 $\mathrm{mg}, 0.0164 \mathrm{mmol}, 96 \%$ yield) as a yellow solid.

M.p. $>300{ }^{\circ} \mathrm{C}$.

IR (KBr) $v_{\mathrm{C}=\mathrm{O}} 1700,1750 \mathrm{~cm}^{-1}, v_{\mathrm{NH}, \mathrm{OH}} 3200-3600 \mathrm{~cm}^{-1}$.

HRMS (FAB+) $[\mathrm{M}+\mathrm{H}]^{+}$calcd for $\mathrm{C}_{26} \mathrm{H}_{22} \mathrm{~N}_{5} \mathrm{O}_{9}$ 548.1417 found, 548.1408 .

${ }^{1} \mathrm{H}$ NMR (400 MHz, $\left.\mathrm{CDCl}_{3}\right): 3.23\left(3 \mathrm{H}, \mathrm{s}, \mathrm{NCH}_{3}\right), 3.52-$ $3.59(2 \mathrm{H}, \mathrm{m}), 3.89(1 \mathrm{H}, \mathrm{d}, J=10.5 \mathrm{~Hz}), 3.99(2 \mathrm{H}$, br s $), 4.10$ $(1 \mathrm{H}, \mathrm{d}, J=10.5 \mathrm{~Hz}), 4.97(1 \mathrm{H}, \mathrm{d}, J=4.5 \mathrm{~Hz}, \mathrm{OH}), 5.17(1 \mathrm{H}$, d, $J=4.0 \mathrm{~Hz}, \mathrm{OH}), 5.41(1 \mathrm{H}$, br s, OH), $6.27(1 \mathrm{H}$, br s, OH), $6.62\left(1 \mathrm{H}, \mathrm{d}, J=9.5 \mathrm{~Hz}, \mathrm{H}_{1}\right), 7.53(1 \mathrm{H}, \mathrm{m}), 7.84(1 \mathrm{H}, \mathrm{d}, J=$ $8.0 \mathrm{~Hz}), 8.50(1 \mathrm{H}, \mathrm{d}, J=8.0 \mathrm{~Hz}), 8.67(1 \mathrm{H}, \mathrm{m}), 9.31(1 \mathrm{H}, \mathrm{d}$, $J=8.0 \mathrm{~Hz}), 9.98(1 \mathrm{H}, \mathrm{s}), 12.14\left(1 \mathrm{H}, \mathrm{s}, \mathrm{NH}_{\mathrm{ind}}\right)$.

Due to the insolubility of compound $\mathbf{1 3}$, its ${ }^{13} \mathrm{C}$ NMR spectrum could not be recorded.

3.9. 6-Methyl-12-(6-chloro-6-deoxy- $\beta$-D-glucopyranos-1yl)-5,7-dihydro-13H-pyrido $\left[3^{\prime}, 2^{\prime}: 4,5\right]$ pyrrolo[2,3a]pyrrolo[3,4-c]carbazole-5,7-dione (14) and 6-methyl12-(3,6-dichloro-3,6-dideoxy- $\beta$-D-allopyranosyl)-5,7dihydro-13H-pyrido $\left[3^{\prime}, 2^{\prime}: 4,5\right]$ pyrrolo[2,3-a]pyrrolo[3,4c]carbazole-5,7-dione (15)

To a solution of $\mathbf{5}(100 \mathrm{mg}, 0.189 \mathrm{mmol})$ in pyridine $(2 \mathrm{ml})$ was added triphenylphosphine $(2.01 \mathrm{~g}, 0.766 \mathrm{mmol})$ then $\mathrm{CCl}_{4}$ ( $39 \mu \mathrm{l}, 0.401 \mathrm{mmol})$. The mixture was stirred at room temperature for $24 \mathrm{~h}$ then poured into water. After extraction with EtOAc, the organic phase was successively washed with $1 \mathrm{~N}$ $\mathrm{HCl}$, water, and a saturated aqueous $\mathrm{NaHCO}_{3}$ solution. The organic phase was dried over $\mathrm{MgSO}_{4}$. After removal of the solvent, the residue was purified by flash chromatography (eluent: from EtOAc/cyclohexane 8:2 to $100 \%$ EtOAc) to afford 14 (15 mg, $0.030 \mathrm{mmol}, 15 \%$ yield) and 15 (26.3 mg, $0.049 \mathrm{mmol}, 24 \%$ yield) as yellow solids.

14:

M.p. $297-300^{\circ} \mathrm{C}$ (decomposition)

IR (KBr) $v_{\mathrm{C}=\mathrm{O}} 1695,1750 \mathrm{~cm}^{-1}, v_{\mathrm{NH}, \mathrm{OH}} 3090-3600 \mathrm{~cm}^{-1}$.

HRMS (FAB+) $[\mathrm{M}+\mathrm{H}]^{+}$calcd for $\mathrm{C}_{26} \mathrm{H}_{22} \mathrm{~N}_{4} \mathrm{O}_{6} \mathrm{Cl}$ 521.1227, found 521.1214 .

${ }^{1} \mathrm{H}$ NMR (400 MHz, DMSO- $d_{6}$ ): ${ }^{\text {amajor conformer, }}{ }^{\mathrm{b}} \mathrm{mi}-$ nor conformer:

$3.20\left(3 \mathrm{H}^{\mathrm{a}}, \mathrm{s}, \mathrm{CH}_{3}\right), 3.21\left(3 \mathrm{H}^{\mathrm{b}}, \mathrm{s}, \mathrm{CH}_{3}\right), 3.56-4.46\left(6 \mathrm{H}^{\mathrm{a}}+\right.$ $\left.6 \mathrm{H}^{\mathrm{b}}\right), 5.11\left(1 \mathrm{H}^{\mathrm{b}}, \mathrm{d}, J=5.5 \mathrm{~Hz}, \mathrm{OH}\right), 5.26\left(2 \mathrm{H}^{\mathrm{a}}, \mathrm{pt}, J=5,0 \mathrm{~Hz}\right.$, $\mathrm{OH}), 5.36\left(1 \mathrm{H}^{\mathrm{b}}, \mathrm{t}, J=5.5 \mathrm{~Hz}, \mathrm{OH}\right), 5.63\left(1 \mathrm{H}^{\mathrm{a}}, \mathrm{m}, \mathrm{OH}\right), 5.85$ $\left(1 \mathrm{H}^{\mathrm{b}}, \mathrm{d}, J=5.0 \mathrm{~Hz}, \mathrm{OH}\right), 6.41\left(1 \mathrm{H}^{\mathrm{b}}, \mathrm{d}, J=9.0 \mathrm{~Hz}, \mathrm{H}_{1}\right), 6.58$ $\left(1 \mathrm{H}^{\mathrm{a}}, \mathrm{d}, J=9.0 \mathrm{~Hz}, \mathrm{H}_{1^{\prime}}\right), 7.42-7.51\left(2 \mathrm{H}^{\mathrm{a}}+2 \mathrm{H}^{\mathrm{b}}, \mathrm{m}\right), 7.57$ $\left(1 \mathrm{H}^{\mathrm{a}}, \mathrm{t}, J=7.5 \mathrm{~Hz}\right), 7.66\left(1 \mathrm{H}^{\mathrm{b}}, \mathrm{t}, J=7.5 \mathrm{~Hz}\right), 8.06\left(1 \mathrm{H}^{\mathrm{a}}, \mathrm{d}\right.$, $J=8.0 \mathrm{~Hz}), 8.09\left(1 \mathrm{H}^{\mathrm{b}}, \mathrm{d}, J=8.0 \mathrm{~Hz}\right), 8.64\left(1 \mathrm{H}^{\mathrm{b}}, \mathrm{d}\right.$, $J=5.0 \mathrm{~Hz}), 8.67\left(1 \mathrm{H}^{\mathrm{a}}, \mathrm{dd}, J_{I}=5.0 \mathrm{~Hz}, J_{2}=1.0 \mathrm{~Hz}\right), 9.16$ $\left(1 \mathrm{H}^{\mathrm{b}}, \mathrm{d}, J=8.0 \mathrm{~Hz}\right), 9.23\left(1 \mathrm{H}^{\mathrm{a}}, \mathrm{d}, J=8.0 \mathrm{~Hz}\right), 9.29\left(1 \mathrm{H}^{\mathrm{b}}, \mathrm{d}\right.$, $J=8.0 \mathrm{~Hz}), 9.35\left(1 \mathrm{H}^{\mathrm{a}}, \mathrm{dd}, J_{I}=8.0 \mathrm{~Hz}, J_{2}=1.0 \mathrm{~Hz}\right), 10.87$ $\left(1 \mathrm{H}^{\mathrm{b}}, \mathrm{s}, \mathrm{NH}\right), 12.75\left(1 \mathrm{H}^{\mathrm{a}}, \mathrm{s}, \mathrm{NH}\right)$.

${ }^{13} \mathrm{CNMR}\left(100 \mathrm{MHz}, \mathrm{DMSO}-d_{6}\right): 23.7\left(\mathrm{NCH}_{3}\right), 44.6,45.4$ $\left(\mathrm{C}_{6^{\prime}}\right), 69.0,69.9,70.8,73.0,75.9,76.0,76.7,77.2,84.8,86.0$
$\left(\mathrm{C}_{1^{\prime}}, \mathrm{C}_{2^{\prime}}, \mathrm{C}_{3^{\prime}}, \mathrm{C}_{4^{\prime}}, \mathrm{C}_{5^{\prime}}\right), 111.8,114.7,116.8,117.2,121.7$, 124.6, 126.9, 127.4, 128.6, 131.4, 132.0, 132.5, 147.8, 148.1 (C tert arom), 113.3, 114.1, 114.5, 115.2, 117.3, 119.2, 119.4, 119.8, 120.5, 120.8, 122.6, 126.7, 127.7, 128.8, 129.9, 139.3, $141.5,142.5,152.0,152.9$ (C quat arom), 169.2, 169.4 (2C), $169.5(\mathrm{C}=\mathrm{O})$.

15

M.p. $240-242{ }^{\circ} \mathrm{C}$ (decomposition).

$\operatorname{IR}(\mathrm{KBr}) v_{\mathrm{C}=\mathrm{O}} 1700,1750 \mathrm{~cm}^{-1}, v_{\mathrm{NH} . \mathrm{OH}} 3200-3600 \mathrm{~cm}^{-1}$. HRMS (FAB+) $[\mathrm{M}+\mathrm{H}]^{+}$calcd for $\mathrm{C}_{26} \mathrm{H}_{21} \mathrm{~N}_{4} \mathrm{O}_{5} \mathrm{Cl}_{2}$ 539.0889 , found 539.0893 .

${ }^{1} \mathrm{H}$ NMR (400 MHz, DMSO- $d_{6}$ ) a major conformer, ${ }^{\mathrm{b}} \mathrm{mi}-$ nor conformer: $3.19\left(3 \mathrm{H}^{\mathrm{a}}, \mathrm{s}, \mathrm{CH}_{3}\right), 3.20\left(3 \mathrm{H}^{\mathrm{b}}, \mathrm{s}, \mathrm{CH}_{3}\right), 4.00-$ $4.83\left(6 \mathrm{H}^{\mathrm{a}}+6 \mathrm{H}^{\mathrm{b}}, \mathrm{m}\right), 5.41\left(1 \mathrm{OH}^{\mathrm{a}}+1 \mathrm{OH}^{\mathrm{b}}, \mathrm{d}, J=5.0 \mathrm{~Hz}\right), 5.83$ $\left(1 \mathrm{OH}^{\mathrm{a}}, \mathrm{d}, J=5.5 \mathrm{~Hz}\right), 6.07\left(1 \mathrm{OH}^{\mathrm{b}}, \mathrm{d}, J=5.5 \mathrm{~Hz}\right), 6.54\left(1 \mathrm{H}^{\mathrm{b}}\right.$, d, $\left.J=9.5 \mathrm{~Hz}, \mathrm{H}_{1^{\prime}}\right), 6.69\left(1 \mathrm{H}^{\mathrm{a}}, \mathrm{d}, J=8.5 \mathrm{~Hz}, \mathrm{H}_{1^{\prime}}\right), 7.42-7.50$ $\left(2 \mathrm{H}^{\mathrm{a}}+2 \mathrm{H}^{\mathrm{b}}, \mathrm{m}\right), 7.58\left(1 \mathrm{H}^{\mathrm{a}}, \mathrm{t}, J=7.5 \mathrm{~Hz}\right), 7.67\left(1 \mathrm{H}^{\mathrm{b}}, \mathrm{t}\right.$, $J=7.5 \mathrm{~Hz}), 7.87\left(1 \mathrm{H}^{\mathrm{b}}, \mathrm{d}, J=8.5 \mathrm{~Hz}\right), 8.12\left(1 \mathrm{H}^{\mathrm{a}}, \mathrm{d}\right.$, $J=8.5 \mathrm{~Hz}), 8.62-8.66\left(1 \mathrm{H}^{\mathrm{a}}+1 \mathrm{H}^{\mathrm{b}}, \mathrm{m}\right), 9.18\left(1 \mathrm{H}^{\mathrm{a}}+1 \mathrm{H}^{\mathrm{b}}, \mathrm{pt}\right.$, $J=8.5 \mathrm{~Hz}), 9.31\left(1 \mathrm{H}^{\mathrm{a}}+1 \mathrm{H}^{\mathrm{b}}, \mathrm{pt}, J=7.5 \mathrm{~Hz}\right), 10.87\left(1 \mathrm{H}^{\mathrm{b}}, \mathrm{s}\right.$, $\mathrm{NH}), 12.71\left(1 \mathrm{H}^{\mathrm{a}}, \mathrm{s}, \mathrm{NH}\right)$.

${ }^{13} \mathrm{C}$ NMR (100 MHz, DMSO- $\left.d_{6}\right): 23.7\left(\mathrm{NCH}_{3}\right), 39.9,40.1$ (CHCl), 44.5, 45.3 ( $\left.\mathrm{CH}_{2} \mathrm{Cl}\right), 65.2,65.7,68.1,69.2,73.6,75.3$, 82.5, 83.6 $\left(\mathrm{C}_{1^{\prime}}, \mathrm{C}_{2^{\prime}}, \mathrm{C}_{4^{\prime}}, \mathrm{C}_{5^{\prime}}\right), 111.5,115.1,116.9,117.3,121.3$, $121.5,124.5,124.6,127.0,127.7,132.5,147.9,148.1$ (C tert arom), 113.8, 114.2, 115.6, 117.7, 119.4, 120.1, 120.7, 121.0, $123.1,127.9,140.3,142.4,144.5,152.0,153.2$ (Cquat arom), $169.1,169.2(\mathrm{C}=\mathrm{O})$.

3.10. 6-Methyl-12-(6-azido-6-deoxy- $\beta$-D-glucopyranos-1yl)-5,7-dihydro-13H-pyrido[3',2':4,5]pyrrolo[2,3a]pyrrolo[3,4-c]carbazole-5,7-dione (17)

A mixture of compound $14(16.5 \mathrm{mg}, 0.0316 \mathrm{mmol})$ in DMF ( $2 \mathrm{ml})$ and $\mathrm{NaN}_{3}(21 \mathrm{mg}, 0.317 \mathrm{mmol})$ was stirred at $90{ }^{\circ} \mathrm{C}$ for 5 days. EtOAc was added and the solution was washed with brine. The organic phase was dried over $\mathrm{MgSO}_{4}$ and the solvent was removed. The residue was purified by flash chromatography (eluent: EtOAc) to afford 17 (12 mg, $0.0227 \mathrm{mmol}, 72 \%$ yield) as a yellow solid.

M.p. $208-212^{\circ} \mathrm{C}$

IR $(\mathrm{KBr}) v_{\mathrm{C}=\mathrm{O}} 1700,1750 \mathrm{~cm}^{-1}, v_{\mathrm{N} 3} 2120 \mathrm{~cm}^{-1}, v_{\mathrm{NH}, \mathrm{OH}}$ $3200-3600 \mathrm{~cm}^{-1}$.

HRMS (FAB+) $[\mathrm{M}+\mathrm{H}]^{+}$calcd for $\mathrm{C}_{26} \mathrm{H}_{22} \mathrm{~N}_{7} \mathrm{O}_{6} 528.1631$, found 528.1626 .

${ }^{1} \mathrm{H}$ NMR (400 MHz, DMSO- $\left.d_{6}\right): 3.26\left(3 \mathrm{H}, \mathrm{s}, \mathrm{CH}_{3}\right), 3.27$ $\left(3 \mathrm{H}, \mathrm{s}, \mathrm{CH}_{3}\right), 3.60-4.35(12 \mathrm{H}, \mathrm{m}), 5.14(1 \mathrm{H}, \mathrm{d}, J=5.0 \mathrm{~Hz}$, $\mathrm{OH}), 5.30(1 \mathrm{H}, \mathrm{d}, J=5.0 \mathrm{~Hz}, \mathrm{OH}), 5.31(1 \mathrm{H}, \mathrm{d}, J=5.0 \mathrm{~Hz}$, $\mathrm{OH}), 5.35(1 \mathrm{H}, \mathrm{t}, J=5.5 \mathrm{~Hz}, \mathrm{OH}), 5.60(1 \mathrm{H}, \mathrm{d}, J=5.5 \mathrm{~Hz}$, $\mathrm{OH}), 5.87(1 \mathrm{H}, \mathrm{d}, J=5.0 \mathrm{~Hz}, \mathrm{OH}), 6.40(1 \mathrm{H}, \mathrm{d}, J=8.5 \mathrm{~Hz}$, $\left.\mathrm{H}_{1^{\prime}}\right), 6.60\left(1 \mathrm{H}, \mathrm{d}, J=9.0 \mathrm{~Hz}, \mathrm{H}_{1}\right), 7.45-7.56(4 \mathrm{H}, \mathrm{m}), 7.64$ $(1 \mathrm{H}, \mathrm{t}, J=7.0 \mathrm{~Hz}), 7.69(1 \mathrm{H}, \mathrm{t}, J=7.0 \mathrm{~Hz}), 8.07(1 \mathrm{H}, \mathrm{d}$, $J=8.0 \mathrm{~Hz}), 8.08(1 \mathrm{H}, \mathrm{d}, J=8.0 \mathrm{~Hz}), 8.69(1 \mathrm{H}, \mathrm{dd}$, $\left.J_{1}=5.0 \mathrm{~Hz}, J_{2}=1.5 \mathrm{~Hz}\right), 8.73\left(1 \mathrm{H}, \mathrm{dd}, J_{1}=5.0 \mathrm{~Hz}\right.$, $\left.J_{2}=1.5 \mathrm{~Hz}\right), 9.21(1 \mathrm{H}, \mathrm{d}, J=8.0 \mathrm{~Hz}), 9.29(1 \mathrm{H}, \mathrm{d}, J=8.0 \mathrm{~Hz})$, 
$9.35\left(1 \mathrm{H}, \mathrm{dd}, J_{I}=7.5 \mathrm{~Hz}, J_{2}=1.0 \mathrm{~Hz}\right), 9.41(1 \mathrm{H}, \mathrm{dd}$, $\left.J_{I}=8.0 \mathrm{~Hz}, J_{2}=1.5 \mathrm{~Hz}\right), 11.24(1 \mathrm{H}, \mathrm{s}, \mathrm{NH}), 12.82(1 \mathrm{H}, \mathrm{s}$, $\mathrm{NH})$.

${ }^{13} \mathrm{CNMR}\left(100 \mathrm{MHz}, \mathrm{DMSO}-d_{6}\right): 23.7\left(\mathrm{NCH}_{3}\right), 50.2,51.4$ $\left(\mathrm{C}_{6^{\prime}}\right), 69.1,70.2,70.8,73.1,76.3(2 \mathrm{C}), 76.7,76.8,84.5,86.2$ $\left(\mathrm{C}_{1^{\prime}}, \mathrm{C}_{2^{\prime}}, \mathrm{C}_{3^{\prime}}, \mathrm{C}_{4^{\prime}}, \mathrm{C}_{5^{\prime}}\right), 111.8,114.5,116.8,117.2,120.9$, 121.1, 124.4, 124.6, 126.9, 127.3, 132.4, 132.5, 147.8, 148.2 (C tert arom), 111.9, 113.4, 114.1, 114.6, 115.2, 117.3, 119.2, $119.3,119.8,120.5,120.8,122.6,127.7,127.8,129.9,139.3$, $142.3,142.5,152.2,152.9$ (Cquat arom), 169.3, $169.4(\mathrm{C}=\mathrm{O})$.

3.11. 6-Methyl-12-(6-iodo-6-deoxy- $\beta$-D-glucopyranos-1yl)-5,7-dihydro-13H-pyrido[3',2':4,5]pyrrolo[2,3a]pyrrolo[3,4-c]carbazole-5,7-dione (16) and 6-methyl12-(6-azido-6-deoxy- $\beta$-D-glucopyranos-1-yl)-1-(2-oxopropyl)-5,7-dihydro-13H-pyrido [3',2':4,5]pyrrolo[2,3a]pyrrolo[3,4-c]carbazole-5,7-dione (20)

To a solution of $14(36 \mathrm{mg}, 0.069 \mathrm{mmol})$ in acetone $(4 \mathrm{ml})$ was added sodium iodide $(210 \mathrm{mg}, 1.38 \mathrm{mmol})$. The mixture was refluxed for 12 days. After addition of EtOAc, the mixture was washed with brine. The organic phase was dried over $\mathrm{MgSO}_{4}$ and the solvent was removed. The residue was purified by flash chromatography (eluent: from EtOAc/ cyclohexane 8:2 to EtOAc $100 \%$ ) to give $\mathbf{1 6}$ as a yellow solid (21.7 $\mathrm{mg}, 0.035 \mathrm{mmol}, 51 \%$ yield) and $\mathbf{2 0}$ as an orange solid (11.1 $\mathrm{mg}, 0.016 \mathrm{mmol}, 24 \%$ yield).

16:

M.p. $255-260^{\circ} \mathrm{C}$ (decomposition).

IR $(\mathrm{KBr}), v_{\mathrm{C}=\mathrm{O}}=1695,1750 \mathrm{~cm}^{-1} ; v_{\mathrm{NH}, \mathrm{OH}}=3000$ $3600 \mathrm{~cm}^{-1}$.

HRMS (FAB+) $[\mathrm{M}+\mathrm{H}]^{+}$calcd for $\mathrm{C}_{26} \mathrm{H}_{21} \mathrm{IN}_{4} \mathrm{O}_{6} 613.0584$, found 613.0582 .

${ }^{1} \mathrm{H}$ NMR (400 MHz, DMSO- $\left.d_{6}\right)$ : ${ }^{\text {a }}$ major conformer, ${ }^{\mathrm{b}}$ minor conformer:

$3.23\left(3 \mathrm{H}^{\mathrm{a}}, \mathrm{s}, \mathrm{CH}_{3}\right), 3.25\left(3 \mathrm{H}^{\mathrm{b}}, \mathrm{s}, \mathrm{CH}_{3}\right), 3.50\left(1 \mathrm{H}^{\mathrm{a}}+1 \mathrm{H}^{\mathrm{b}}, \mathrm{t}\right.$, $J=8.5 \mathrm{~Hz}), 3.70-3.95\left(4 \mathrm{H}^{\mathrm{a}}+4 \mathrm{H}^{\mathrm{b}}, \mathrm{m}\right), 4.01\left(1 \mathrm{H}^{\mathrm{a}}+1 \mathrm{H}^{\mathrm{b}}, \mathrm{t}\right.$, $J=8.5 \mathrm{~Hz}), 5.15\left(1 \mathrm{H}^{\mathrm{b}}\right.$, br s, OH$), 5.28\left(2 \mathrm{H}^{\mathrm{a}}\right.$, br s, OH), 5,40 $\left(1 \mathrm{H}^{\mathrm{b}}\right.$, br s, OH), $5.63\left(1 \mathrm{H}^{\mathrm{a}}\right.$, br s, OH), $5.84\left(1 \mathrm{H}^{\mathrm{b}}\right.$, br s, OH), $6.45\left(1 \mathrm{H}^{\mathrm{b}}, \mathrm{d}, J=9.0 \mathrm{~Hz}, \mathrm{H}_{1^{\prime}}\right), 6.61\left(1 \mathrm{H}^{\mathrm{a}}, \mathrm{d}, J=8.5 \mathrm{~Hz}, \mathrm{H}_{1^{\prime}}\right)$, $7.42-7.52\left(2 \mathrm{H}^{\mathrm{a}}+2 \mathrm{H}^{\mathrm{b}}, \mathrm{m}\right), 7.61\left(1 \mathrm{H}^{\mathrm{a}}, \mathrm{t}, J=7.5 \mathrm{~Hz}\right), 7.69$ $\left(1 \mathrm{H}^{\mathrm{b}}, \mathrm{t}, J=7.5 \mathrm{~Hz}\right), 8.11\left(1 \mathrm{H}^{\mathrm{b}}, \mathrm{d}, J=9.0 \mathrm{~Hz}\right), 8.21\left(1 \mathrm{H}^{\mathrm{a}}, \mathrm{d}\right.$, $J=8.5 \mathrm{~Hz}), 8.66\left(1 \mathrm{H}^{\mathrm{b}}, \mathrm{dd}, J_{1}=4.5 \mathrm{~Hz}, J_{2}=1.5 \mathrm{~Hz}\right), 8.70$ $\left(1 \mathrm{H}^{\mathrm{a}}, \mathrm{dd}, J_{1}=4.5 \mathrm{~Hz}, J_{2}=1.5 \mathrm{~Hz}\right), 9.19\left(1 \mathrm{H}^{\mathrm{b}}, \mathrm{d}, J=8.0 \mathrm{~Hz}\right)$, $9.26\left(1 \mathrm{H}^{\mathrm{a}}, \mathrm{d}, J=8.0 \mathrm{~Hz}\right), 9.34\left(1 \mathrm{H}^{\mathrm{b}}, \mathrm{dd}, J_{l}=7.0 \mathrm{~Hz}\right.$, $\left.J_{2}=1.0 \mathrm{~Hz}\right), 9.37\left(1 \mathrm{H}^{\mathrm{a}}\right.$, dd, $\left.J_{1}=7.5 \mathrm{~Hz}, J_{2}=1.5 \mathrm{~Hz}\right), 10.74$ $\left(1 \mathrm{H}^{\mathrm{b}}, \mathrm{s}, \mathrm{NH}\right), 12.79\left(1 \mathrm{H}^{\mathrm{a}}, \mathrm{s}, \mathrm{NH}\right)$.

${ }^{13} \mathrm{C}$ NMR $\left(100 \mathrm{MHz}\right.$, DMSO- $\left.d_{6}\right)$ major conformer: 10.8 $\left(\mathrm{CH}_{2} \mathrm{I}\right), 23.8\left(\mathrm{NCH}_{3}\right), 70.8,73.3,74.9,75.8,85.9\left(\mathrm{C}_{1^{\prime}}, \mathrm{C}_{2^{\prime}}\right.$, $\left.\mathrm{C}_{3^{\prime}}, \mathrm{C}_{4^{\prime}}, \mathrm{C}_{5^{\prime}}\right), 115.2,116.8,121.2,124.6,126.8,132.4,147.9$ (C tert arom), 113.4, 117.3, 119.2, 119.9, 122.6, 126.9, 130.0, 139.3, 152.2, 152.9 (C quat arom), 169.4, $169.5(\mathrm{C}=\mathrm{O})$.

20:

M.p. $230-235^{\circ} \mathrm{C}$ (decomposition).

IR $(\mathrm{KBr}), v_{\mathrm{OH}}=1690,1700,1730 \mathrm{~cm}^{-1} ; v_{\mathrm{OH}}=3200-$ $3650 \mathrm{~cm}^{-1}$.
HRMS (FAB+) $[\mathrm{M}+\mathrm{H}]^{+}$calcd for $\mathrm{C}_{29} \mathrm{H}_{25} \mathrm{IN}_{4} \mathrm{O}_{7} 669.0846$, found 669.0856 .

${ }^{1} \mathrm{H}$ NMR (400 MHz, DMSO- $d_{6}$ ): ${ }^{\text {a }}$ major conformer, ${ }^{\mathrm{b}}$ minor conformer.

$2.50\left(3 \mathrm{H}^{\mathrm{a}}+3 \mathrm{H}^{\mathrm{b}}, \mathrm{s}, \mathrm{CH}_{3}\right), 3.25\left(3 \mathrm{H}^{\mathrm{a}}+3 \mathrm{H}^{\mathrm{b}}, \mathrm{s}, \mathrm{CH}_{3}\right), 3.42-$ $3.78\left(4 \mathrm{H}^{\mathrm{a}}+4 \mathrm{H}^{\mathrm{b}}, \mathrm{m}\right), 4.00-4.22\left(2 \mathrm{H}^{\mathrm{a}}+2 \mathrm{H}^{\mathrm{b}}, \mathrm{m}\right), 5.04\left(1 \mathrm{H}^{\mathrm{a}}, \mathrm{d}\right.$, $J=5.5 \mathrm{~Hz}, \mathrm{OH}), 5.06\left(1 \mathrm{H}^{\mathrm{b}}, \mathrm{d}, J=5.5 \mathrm{~Hz}, \mathrm{OH}\right), 5.31\left(1 \mathrm{H}^{\mathrm{a}}, \mathrm{d}\right.$, $J=5.0 \mathrm{~Hz}, \mathrm{OH}), 5.33\left(1 \mathrm{H}^{\mathrm{b}}, \mathrm{d}, J=5.0 \mathrm{~Hz}, \mathrm{OH}\right), 5.63\left(1 \mathrm{H}^{\mathrm{a}}, \mathrm{d}\right.$, $J=5.0 \mathrm{~Hz}), 5.66\left(1 \mathrm{H}^{\mathrm{b}}, \mathrm{d}, J=5.0 \mathrm{~Hz}\right), 5.86\left(2 \mathrm{H}^{\mathrm{a}}+2 \mathrm{H}^{\mathrm{b}}, \mathrm{AB}\right.$ system, $J=17.5 \mathrm{~Hz}, \Delta v=24 \mathrm{~Hz}), 7.41-7.48\left(2 \mathrm{H}^{\mathrm{a}}+2 \mathrm{H}^{\mathrm{b}}, \mathrm{m}\right)$, $7.60\left(1 \mathrm{H}^{\mathrm{a}}+1 \mathrm{H}^{\mathrm{b}}, \mathrm{dt}, J_{1}=7.0 \mathrm{~Hz}, J_{2}=1.5 \mathrm{~Hz}\right), 7.83\left(1 \mathrm{H}^{\mathrm{b}}, \mathrm{d}\right.$, $\left.J=9.0 \mathrm{~Hz}, \mathrm{H}_{1^{\prime}}\right), 7.87\left(1 \mathrm{H}^{\mathrm{a}}, \mathrm{d}, J=9.0 \mathrm{~Hz}, \mathrm{H}_{1^{\prime}}\right), 7.99\left(1 \mathrm{H}^{\mathrm{b}}, \mathrm{d}\right.$, $J=8.5 \mathrm{~Hz}), 8.08\left(1 \mathrm{H}^{\mathrm{a}}, \mathrm{d}, J=8.5 \mathrm{~Hz}\right), 8.47\left(1 \mathrm{H}^{\mathrm{b}}, \mathrm{dd}\right.$, $\left.J_{1}=6.5 \mathrm{~Hz}, J_{2}=1.5 \mathrm{~Hz}\right), 9.19\left(1 \mathrm{H}^{\mathrm{a}}+1 \mathrm{H}^{\mathrm{b}}, \mathrm{dd}, J_{I}=8.0 \mathrm{~Hz}\right.$, $\left.J_{2}=1.0 \mathrm{~Hz}\right), 9.49\left(1 \mathrm{H}^{\mathrm{a}}+1 \mathrm{H}^{\mathrm{b}}, \mathrm{dd}, J_{I}=7.5 \mathrm{~Hz}, J_{2}=1.0 \mathrm{~Hz}\right)$.

${ }^{13} \mathrm{C}$ NMR (100 MHz, DMSO- $d_{6}$ ) major conformer: 10.4 $\left(\mathrm{CH}_{2} \mathrm{I}\right), 23.6,27.7\left(\mathrm{CH}_{3}\right), 64.0\left(\mathrm{CH}_{2}\right), 71.0,73.4,76.2,77.0$, 85.7 $\left(\mathrm{C}_{1^{\prime}}, \mathrm{C}_{2^{\prime}}, \mathrm{C}_{3^{\prime}}, \mathrm{C}_{4^{\prime}}, \mathrm{C}_{5^{\prime}}\right), 109.8,114.2,120.6,124.4,126.2$, 136.0, 137.6 (C tert arom), 116.1, 116.2, 117.6, 120.3, 122.7, $122.9,139.2,142.5,152.6$ (C quat arom), $170.0(2 \mathrm{C})(\mathrm{C}=\mathrm{O})$, $200.5(\mathrm{C}=\mathrm{O})$.

3.12. 6-Methyl-12-( $\beta$-D-glucopyranos-1-yl)-7-oxo-13Hpyrido[3',2':4,5]pyrrolo[2,3-a]pyrrolo[3,4-c]carbazole and 6-methyl-12-( $\beta$-D-glucopyranos-1-yl)-5-oxo-13Hpyrido[3',2':4,5]pyrrolo[2,3-a]pyrrolo[3,4-c]carbazole (19)

$6 \mathrm{~N} \mathrm{HCl}(870 \mu \mathrm{l})$ was added to a suspension of $7(34 \mathrm{mg}$, $0.067 \mathrm{mmol})$ in ethanol $(5 \mathrm{ml})$ before addition of zinc amalgam (572 mg). The mixture was refluxed for $24 \mathrm{~h}$, and water was added. After extraction with EtOAc, the organic phase was washed with saturated aqueous $\mathrm{NaHCO}_{3}$ then with brine. The organic phase was dried over $\mathrm{MgSO}_{4}$, the solvent was removed and the residue was purified by flash chromatography (eluent: from EtOAc to EtOAc/methanol 9:1) to give 19 (13 mg, $0.026 \mathrm{mmol}, 40 \%$ yield) as a white solid (mixture of regioisomers). The regioisomeric ratio determined from ${ }^{1} \mathrm{H}$ NMR spectrum on the signals at 9.41 and $9.51 \mathrm{ppm}$ was $1: 1$.

HRMS (FAB+) $[\mathrm{M}+\mathrm{H}]^{+}$calcd for $\mathrm{C}_{26} \mathrm{H}_{25} \mathrm{~N}_{4} \mathrm{O}_{6} 489.1774$, found 489.1773 .

IR $(\mathrm{KBr}) v_{\mathrm{C}=\mathrm{O}} 1660 \mathrm{~cm}^{-1}, v_{\mathrm{NH}, \mathrm{OH}} 3200-3600 \mathrm{~cm}^{-1}$.

${ }^{1} \mathrm{H}$ NMR (400 MHz, DMSO-d $)$ : 3.19, $3.20\left(6 \mathrm{H}, 2 \mathrm{~s}, \mathrm{CH}_{3}\right)$, $3.60-4.12(12 \mathrm{H}, \mathrm{m}), 5.03$ (1H, br s, OH), $5.11(1 \mathrm{H}, \mathrm{br} \mathrm{s}, \mathrm{OH})$, $5.40\left(4 \mathrm{H}, \mathrm{dd}, J_{1}=6.0 \mathrm{~Hz}, J_{2}=2.0 \mathrm{~Hz}\right), 5.52(2 \mathrm{H}, \mathrm{br} \mathrm{s}, \mathrm{OH})$, $5.63(2 \mathrm{H}, \mathrm{m}, \mathrm{OH}), 6.27\left(2 \mathrm{H}, \mathrm{dt}, J_{1}=6.0 \mathrm{~Hz}, J_{2}=2.0 \mathrm{~Hz}\right.$, $\mathrm{OH}), 6.54\left(1 \mathrm{H}, \mathrm{d}, J=9.5 \mathrm{~Hz}, \mathrm{H}_{1}\right), 6.56(1 \mathrm{H}, \mathrm{d}, J=9.5 \mathrm{~Hz}$, $\left.\mathrm{H}_{1}\right), 7.33-7.62(6 \mathrm{H}, \mathrm{m}), 7.96(1 \mathrm{H}, \mathrm{d}, J=8.0 \mathrm{~Hz}), 7.99(1 \mathrm{H}$, $\mathrm{d}, J=8.0 \mathrm{~Hz}), 8.45(1 \mathrm{H}, \mathrm{t}, J=7.5 \mathrm{~Hz}), 8.50-8.60(2 \mathrm{H}, \mathrm{m})$, $8.71(1 \mathrm{H}, \mathrm{t}, J=8.5 \mathrm{~Hz}), 9.41(1 \mathrm{H}, \mathrm{d}, J=8.0 \mathrm{~Hz}), 9.51(1 \mathrm{H}, \mathrm{d}$, $J=8.0 \mathrm{~Hz}), 11.75$ (2H, br s, NH).

Growth inhibition assays. Tumor cells were provided by American Type Culture Collection (Frederik, MD, USA). They were cultivated in RPMI 1640 medium (Life Science Technologies, Cergy-Pontoise, France) supplemented with $10 \%$ fetal calf serum, $2 \mathrm{mM} \mathrm{L}$-glutamine, 100 units $\mathrm{ml}^{-1}$ peni- 
cillin, $100 \mu \mathrm{g} \mathrm{ml}^{-1}$ streptomycin, and $10 \mathrm{mM}$ HEPES buffer ( $\mathrm{pH}$ 7.4). Cytotoxicity was measured by the microculture tetrazolium assay as described [24]. Cells were continuously exposed to graded concentrations of the compounds for four doubling times ( $48 \mathrm{~h}$ for L1210 cells, $120 \mathrm{~h}$ for DU145 cells, and $96 \mathrm{~h}$ for A549 and HT29 cells), then $15 \mu \mathrm{l}$ of $5 \mathrm{mg} \mathrm{ml}^{-1}$ 3-(4,5-dimethylthiazol-2-yl)-2,5-diphenyltetrazolium bromide were added to each well and the plates were incubated for $4 \mathrm{~h}$ at $37{ }^{\circ} \mathrm{C}$. The medium was then aspirated and the formazan solubilized by $100 \mu \mathrm{l}$ of DMSO. Results are expressed as $\mathrm{IC}_{50}$, concentration which reduced by $50 \%$ the optical density of treated cells with respect to untreated controls.

Cell cycle analysis. For the cell cycle analysis, L1210 cells $\left(2.5 \times 10^{5}\right.$ cells per $\left.\mathrm{ml}\right)$ were incubated for $21 \mathrm{~h}$ with various concentrations of the compounds, then fixed by $70 \%$ ethanol $(\mathrm{v} / \mathrm{v})$, washed and incubated in PBS containing $100 \mu \mathrm{g} \mathrm{ml}^{-1}$ RNAse and $25 \mu \mathrm{g} \mathrm{ml}^{-1}$ propidium iodide for $30 \mathrm{~min}$ at $20^{\circ} \mathrm{C}$. For each sample, $10^{4}$ cells were analyzed on a XL/MCL flow cytometer (Beckman Coulter). The fluorescence of propidium iodide was collected through a $615 \mathrm{~nm}$ long-pass filter.

\section{References}

[1] M. Prudhomme, Curr. Pharm. Des. 3 (1997) 265-290.

[2] J.A. Bush, B.H. Long, J.J. Catino, W.T. Bradner, K. Tomita, J. Antibiot. 40 (1987) 668-678.

[3] C. Bailly, J.-F. Riou, P. Colson, C. Houssier, E. Rodrigues-Pereira, M. Prudhomme, Biochemistry 36 (1997) 3917-3929.

[4] M. Prudhomme, Eur. J. Med. Chem. 38 (2003) 123-140.

[5] B.H. Long, W.C. Rose, D.M. Vyas, J.A. Matson, S. Forenza, Anticancer agents, Curr. Med. Chem. 2 (2002) 255-266.
[6] P. Moreau, N. Gaillard, C. Marminon, F. Anizon, N. Dias, B. Baldeyrou, C. Bailly, A. Pierré, J. Hickman, B. Pfeiffer, P. Renard, M. Prudhomme, Bioorg. Med. Chem. 11 (2003) 4871-4879.

[7] F. Anizon, P. Moreau, M. Sancelme, W. Laine, C. Bailly, M. Prudhomme, Bioorg. Med. Chem. 11 (2003) 3709-3722.

[8] M. Binaschi, M. Bigioni, A. Cipollone, C. Rossi, C. Goso, C.A. Maggi, G. Capranico, F. Animati, Anti-Cancer Agents, Curr. Med. Chem. 1 (2001) 113-130.

[9] C. Marminon, A. Pierré, B. Pfeiffer, V. Pérez, S. Léonce, A. Joubert, C. Bailly, P. Renard, J. Hickman, M. Prudhomme, J. Med. Chem. 46 (2003) 609-622.

[10] C. Marminon, A. Pierré, B. Pfeiffer, V. Pérez, S. Léonce, P. Renard, M. Prudhomme, Bioorg. Med. Chem. 11 (2003) 679-687.

[11] Y. Chen, P. Vogel, J. Org. Chem. 59 (1994) 2487-2496.

[12] S. Blanchard, I. Rodriguez, C. Kuehm-Caubère, P. Renard, B. Pfeiffer, G. Guillaumet, P. Caubère, Tetrahedron 58 (2002) 3513-3524

[13] W. Baik, S. Yun, J.U. Rhee, G.A. Russell, J. Chem, Soc. Perkin Trans I (1996) 1777-1779.

[14] P. Moreau, N. Gaillard, C. Marminon, F. Anizon, N. Dias, B. Baldeyrou, C. Bailly, A. Pierré, J. Hickman, B. Pfeiffer, P. Renard, M. Prudhomme, Bioorg. Med. Chem. 11 (2003) 4871-4879.

[15] C. Marminon, F. Anizon, P. Moreau, S. Léonce, A. Pierré, B. Pfeiffer, P. Renard, M. Prudhomme, J. Med. Chem. 45 (2002) 1330-1339.

[16] E.J. Gilbert, J.D. Chisholm, D.L. Van Vranken, J. Org. Chem. 64 (1999) 5670-5676

[17] P. Moreau, F. Anizon, M. Sancelme, M. Prudhomme, C. Bailly, C. Carrasco, M. Ollier, D. Sevère, J.F. Riou, D. Fabbro, T. Meyer, A.-M. Aubertin, J. Med. Chem. 41 (1998) 1631-1640.

[18] E. Rodrigues Pereira, L. Belin, M. Sancelme, M. Prudhomme, M. Ollier, M. Rapp, D. Sevère, J.F. Riou, D. Fabbro, T. Meyer, J. Med. Chem. 39 (1996) 4471-4477.

[19] F. Goldwasser, I. Bae, M. Valenti, K. Torres, Y. Pommier, Cancer Res. 55 (1995) 2116-2121

[20] J.M. Lord, J. Pongracz, J. Clin. Pathol. Mol. Pathol. 48 (1995) M57M64.

[21] M. Hall, G. Peters, Cancer Res. 68 (1996) 67-108.

[22] Y. Pommier, C. Redon, V.A. Rao, J.A. Seiler, O. Sordet, H. Takemura, S. Anthony, L. Meng, Z. Liao, G. Kohlhagen, H. Zhang, K.W. Kohn, Mutat. Res. 532 (2003) 173-203.

[23] P. Chène, Anti-cancer agents, Curr. Med. Chem. 1 (2001) 151-161.

[24] S. Léonce, V. Pérez, M.R. Casabianca-Pignède, M. Anstett, E. Bisagni, G. Atassi, Invest. New Drugs 14 (1996) 169-180. 